Chapter 20

\title{
Sustainable consumption, consumer protection and sustainable development: Unbundling institutional septet for developing economies
}

\author{
Onyeka K. Osuji \& Ugochi C. Amajuoyi ${ }^{1}$
}

\subsection{Introduction}

This chapter investigates the role of consumption in sustainable development and, drawing on the institutional and stakeholder theoretic models, examines its institutional implications for developing economies. Against the backdrop of concerns about consumerism and responsible business practices, the chapter seeks to identify consumer protection measures that can facilitate a symbiotic relationship between consumption and sustainable development within the framework of the Sustainable Development Goals (SDGs) (United Nations, 2015). These consumer protection measures can assist in protecting 'present' (proximate) consumers and 'future' generations in line with the definition of sustainable development as providing for 'the needs of the present without compromising the ability of future generations to meet their own needs' (United Nations, 1987). The measures can be employed in providing a balance between economic development, social development and environmental protection as the pillars of sustainable development emphasised by the Johannesburg World Summit on Sustainable Development (United Nations, 2002).

Although the linkage between consumption and sustainable development seems widely acknowledged, there has been a limited attention on deploying consumer protection rules to advance sustainable development. This chapter therefore provides an original contribution to

\footnotetext{
${ }^{1}$ We thank Professor Chris Willett for commenting on earlier drafts of this chapter.
} 
the debate on sustainable consumption and production in three main ways. Firstly, it studies sustainable consumption through a new theoretical lens which combines the legal institutional and stakeholder perspectives. Thus far these theoretical models have only been considered separately and in addition, they have not been considered in combination to analyse the developing country context. Secondly, the chapter draws on the SDGs to recommend a septet of foundational components of sustainable consumption and development within the context of developing countries. Thirdly, it is argued that a more interventionist consumer protection approach involving a mix of recognition of consumer vulnerabilities, consumer private law rights, stakeholder rights and responsibilities and administrative enforcement powers can be utilised to align consumption with sustainable development in developing countries.

Before expanding on these arguments, it is useful to underline the contemporary significance of sustainable consumption and production, especially ongoing legitimate concerns over its role and operationalisation in sustainable development in local and global contexts. Originally, the concept of sustainable development was narrowly-focused and primarily conservationdriven. This is exemplified by the International Union for Conservation of Nature and Natural Resources (IUCN), which helped to bring the concept to global consciousness. IUCN formulated the World Conservation Strategy with 'the overall aim of achieving sustainable development through conservation of living resources' (IUCN, 1980). The SDGs, however, underline a shift to a more expansive conception of sustainable development that encompasses a range of other matters including poverty reduction, health and wellbeing, sustainable consumption and production, labour standards, gender equality, anti-corruption and international cooperation. Prior to the SDGs, the United Nations Conference on Environment and Development 1992 highlighted some linkages between consumption and environmental protection. The Johannesburg World Summit on Sustainable Development 2002 had sustainable consumption and production as one of the main goals for sustainable development. 
The 2012 United Nations Conference on Sustainable Development (Rio+20) adopted a tenyear framework of programmes on sustainable consumption and production (UN, 2012) that projected the broader notion of sustainable development. In addition to other references (e.g. articles 5(i), 6 and 7), Part H (articles 49-60) of the UN Guidelines for Consumer Protection (United Nations, 2016) focuses on sustainable consumption.

Consumption arguably plays a dual role in sustainable development. While in the negative sense, consumption can create demands for, and use of, unsustainable products and production methods, it can also limit and realign demands and usages to positively contribute to sustainable development. The SDGs highlight this two-fold importance of efficient consumption to sustainable development by including the Goal 12 broad statement of ensuring 'sustainable consumption and production patterns.' Implicit in the statement is, on the one hand, the acknowledgement of consumers as a significant constituency for sustainable development. For example, by encouraging the efficient use of energy resources and reducing wasteful food consumption within households, largely by placing limits on consumption, the SDGs recognise the key role of consumers in procuring the achievement of sustainable development. On the other hand, Goal 12 confirms a growing recognition that businesses can play vital roles in addressing social issues globally, especially in the developing markets. The willingness and participation of corporations in norm-setting for environmental protection (Falkner, 2003:30) and other areas of sustainable development is crucial for investigating, detecting and communicating evidence and adopting appropriate solutions. The SDGs share this aspiration with other international initiatives such as the UN Global Compact 2000, UN Guiding Principles on Business and Human Rights and OECD Guidelines for Multinational Enterprises 2011. Moreover, the exponential growth of corporate and independent reporting initiatives such as the Global Reporting Initiative's G4 Sustainability Reporting Guidelines and certification programmes such as SA8000 is an indication of the heightened interest of corporate 
constituencies like investors and consumers in sustainable development and other social matters endorsed within the umbrella of corporate social responsibility (CSR).

In addition to the anthropogenic approach of Goal 12, the SDGs also affirm the role of institutions in developing countries. For example, Target 16a of Goal 16 stresses the need to 'strengthen relevant national institutions..., for building capacity at all levels, in particular in developing countries.' Although a global concern, sustainable development may have developing economies-specific strands. A recent report of Christian Aid (2018:4), while noting the contemporary effects of climate change, observed that '[i]n many developing countries the human cost of climate change to vulnerable communities is much higher than the financial cost.' Nonetheless, despite the gravity of threats from unsustainable practices, the relatively inadequate responsiveness in some developing countries sharply contrasts with the more advanced countries.

We have therefore adopted an improved approach by drawing on the SDGs to make an original proposition about the existence of inceptive components of sustainable consumption and production: (a) sustainable consumption by proximate consumers for future generations; (b) sustainable production for future generations; (c) sustainable consumption by/for proximate consumers; (d) sustainable production for proximate consumers; (e) participation by proximate consumers; and (f) corporate social responsibility. These six elements may present distinctive contextual challenges, hence recognising this developing country context makes for seven key elements in total and completes what we can call the septet of implications for sustainable consumption. This septet framework provides clarity to the concept of sustainable consumption and production by identifying, segregating and linking its constituents. It provides fresh insights in the bourgeoning area of sustainable development, especially in the developing country context where attention has mainly concentrated on poverty reduction. The septet approach is unlike existing studies (e.g. Shove, 2004; Bray and Johns, 2011; Antonetti, and 
Maklan, 2014; Newholm et al, 2015; Carrington et al, 2016) which have largely focused on behavioural analyses of consumer behaviour and lifestyle changes. Similarly, 'circular economy' studies emphasise the involvement of corporations/producers and consumers in recycling processes (Winans et al, 2017; Korhonen et al, 2018). The plastic industry is a prominent example of the circular economy campaigns (see European Commission, 2015, 2018). Here, however, the septet framework will be applicable to both factors: consumer/producer behaviours and industry practices.

The septet approach has facilitated the other two original contributions. It prompts us to ask how consumer law rules should be designed in order to deliver on the key elements of the septet approach to sustainable development. In doing so it is original first in adopting a mixed methodology for understanding the links between consumer law rules and sustainable development; and second, based on these links, in making the argument for a more interventionist consumer protection la model to achieve sustainable consumption. Let us now elaborate on this a little. While sustainable consumption can be studied from a range of theoretical lenses, this chapter provides novel solutions to the sustainable development agenda by combining the legal, institutional and stakeholder perspectives. Proceeding on the basis that economic actors such as corporations can be 'distantiated' from responsibility by lack of proximity to stakeholders and regulations (Herlin and Solitander, 2017:10), we argue that delivering on the septet criteria for sustainable development requires a more interventionist consumer protection paradigm in contrast to the current less interventionist and less protective consumer law approach undertaken, for example, by UK and other jurisdictions. However, the current consumer law approach does not achieve this. Rather it involves a less interventionist and less protectionist approach, and crucially, one that does not do enough to promote the key septet criteria for sustainable development. It is important to develop and deepen private participation and enforcement to complement public enforcement within the legal framework 
for sustainable consumption and production. Drawing on the institutional and stakeholder theoretic models, we demonstrate that consumption is an institution and consumers and corporations are groups of institutional actors for sustainable development. We propose a context-specific interventionist approach to provide a framework for aligning consumer protection to sustainable development in the developing markets. The chapter in particular advances knowledge by integrating regulatory debates and applying them to advocate a 'consumer protection' model that reframes consumer vulnerability, disclosure regulation, contract law, consumer responsibilisation, stakeholder roles, corporate governance, institutional voids and international cooperation for sustainable consumption in developing countries.

The rest of the chapter is organised as follows. First, we examine the meaning of institutions and show that legal rules and frameworks can be categorised as 'institutions' as defined by the institutional theoretic model. This is followed by an outline of the meaning of sustainable consumption which shows that within the institutional theoretic model, sustainable consumption can be classified as an institution and, therefore, consumers and corporations are economic and social institutional actors within this theoretical model. The chapter then examines the role of consumption in promoting sustainable development by identifying six foundational components of sustainable consumption and production before considering the developing country context to complete the septet. It then discusses consumer protection, regulatory and stakeholder measures that can positively enhance the role of consumption in promoting sustainable development to show that a symbiotic relationship between consumption and sustainable development is possible within the framework of the SDGs. The final section deals with the key argument as to the importance of strong consumer protection in order to deliver on the septet criteria for sustainable development. So, it shows that for a consumer protection model to be effective within developing countries where regulatory and 
enforcement mechanisms may be weak or non-existent, it is imperative that it is designed in a way that aligns sustainable consumption and production to sustainable development through the recognition of corporations as social institutional actors. It highlights that the original septet framework proffered in this chapter enables this by facilitating the idea of private enforcement of international best standards and a strong consumer protection regime.

\subsection{Institutions and consumption}

We will now look at the institutional theoretic model to show that it can be deployed in explaining the role of sustainable consumption and production in sustainable development. This is because the institutional theory attempts to explain the driving factors for the behaviour and interaction of social actors. Within the institutional theoretic model in the institutional economics movement is the implicit rejection of the neoclassical theory that gives little or no attention to the role of institutions in the market process and outcomes (Rutherford, 2001:187). Accordingly, North (1990:3) defined institutions as 'the rules of the game in a society or, more formally, are the humanly devised constraints that shape human interaction.' Hodgson (2006:2) similarly defined institutions as 'systems of established and prevalent social rules that structure social interactions.'

Law is therefore a class of institution within the institutional theoretic model (Modigliani and Perotti, 1997; Beck and Levine, 2005; Hodgson, 2006). However, there are two divergent views on the role of legal institutions in national economic growth. On the one hand, it is argued that legal institutions create enabling environments by providing for and enforcing, among others, property and investor rights. This links economic growth to the nature of legal rules and the quality of their enforcement (La Porta et al, 1997, 1998, 2000, 2008). Another viewpoint, however, suggests that market-led developments can precede and inspire legal rules in 
countries like the UK and US (Black, 2001; Cheffins, 2001:483-484; Coffee, 2001:65-66; Dam, 2006:188-189). Nonetheless, it is clear from these two schools that legal institutions can play a critical role in shaping and enforcing rules for the market notwithstanding the initial source of the rules. Afterall, institutions of different categories provide incentives for the economic behaviour of social actors (Acemoglu et al, 2002; Chang, 2011).

Although these institutional studies focused on economic growth, the lessons can be extrapolated to sustainable development, particularly as its definition (United Nations, 1987, 2002) suggests balancing present economic development and ethical considerations for present and future generations. It is notable, firstly, that the concept of institutions encompasses both public and private entities. For example, according to North (1990:3) institutions can be 'political, social, or economic' while the categorisation of institutions by Acemoglu et al (2002) is based on the respective influence of economic incentives, geography and culture on behaviour. Implicit in these is the notion of the capability of private individuals and organisations to shape behaviour in society outside the formal political and legal framework. Another inference is that, despite their coercive powers, state agents do not have an exclusive influence on social behaviour and regulatory outcomes. Thirdly, culture is an essential determinant of individual and organisational behaviour. As Hofsted (1994:116) stated, the behaviour of individuals is influenced by 'a structure in their organisations, institutions, and relationships which makes events clearly interpretable and predictable'. This is a reference to culture which Aghion and Howitt (2009:421) defined as individual and collective beliefs, social norms, and various attributes of individuals' preferences that are somehow influenced by their environment, but typically slow moving'. The fourth point is that rules and standards of behaviour can originate from formal and informal non-state agents like individuals, groups and communities who share certain beliefs and values. Sometimes, formal laws and regulations 
simply manifest pre-existing informal rules, customs and attitudes of private persons in society (Easterly, 2008).

The conceptualisation of institutions suggests that, while consumer protection rules are institutions, consumption can be an institution and consumers institutional actors in the social, economic, cultural senses by influencing or incentivising the economic and other behaviours of businesses and social actors. This can be inferred from Acemoglu's (2009:120) description of economic institutions as comprising 'such things as the structure of property rights, the presence of markets, and the contractual opportunities available to individuals and companies.' Similarly, Hodgson (2006:2) identified 'language, money, law, systems of weights and measures, table manners, and firms (and other organisations)' within the categorisation of economic institutions.

Consumption ultimately drives production and innovation. As Mansvelt (2005:1) observed, ' $[t]$ he increased visibility of sites of consumption and the proliferation of consumer goods and images have led social commentators to suggest consumption rather than production is now the driving force in contemporary society.' Consumer tastes and purchasing behaviour influence the emergence, survival and profitability of products and services and the investments needed for their research, formulation and existence. Even in the case of 'new' products and services, their appearance is often linked to expectations of future positive and profitable custom by producers and investors. This also applies to marketing and advertising aimed at influencing consumption which succeeds when consumers are, in fact, attracted to products and services and propel their production patterns. Similarly, when the state encourages or discourages production and consumption along certain lines, the success of the policy depends on the extent of consumption. The long-term prospects of governmental incentives for production is limited if consumption moves in a parallel direction. The institutional approach 
similarly recognises that economic behaviour is a product of the institutional social actors and their beliefs and values which in turn influence their actions (Greif (2006).

The institutional approach therefore underscores the role of law and other institutions in promoting desired behaviours and discouraging undesirable ones. It is useful to identify the relevant activity and institutions that can help to influence behaviours towards the achievement of the goal. This section has shown that, while law is one of the institutions that influence consumption and production, private actors like consumers are also institutional actors in that regard. The next part of this chapter examines consumption as an institutional factor for sustainable development.

\subsection{Sustainable consumption and production}

To consume would ordinarily refer to purchasing and using products and services. The decision to purchase or use may depend on several factors, including physiological and psychological needs, interests, personal preferences, tastes, and beliefs that differ from person to person. These factors can also be influenced by changing sociological circumstances, including law, culture and other institutions. Consequently, it is arguable that 'all human societies have been involved in consumption but the connections between what people do and a sense of them being “consumers" are only found in specific analytic contexts' (Evans et al, 2017:5). Strictly speaking, it may be possible to distinguish between sustainable consumption ('consuming less') and ethical consumption ('consuming differently') (Evans et al, 2017:2) with the former's objective of reduced resource use in production and consumption (Evans, 2011, 2018). Nonetheless, we use sustainable consumption and ethical consumption interchangeably in this chapter since purchasing, using or consuming differently can be influenced by ethical values derived from individual and society orientations. 
The notion of sustainable consumption exists within the individualised and sociological context that 'criss-crosses and works through a multitude of consumption-related behaviours and scales' (Hinton and Goodman, 2010:246). Sustainable consumption can be identified from the essentialist, existentialist, performative and descriptive approaches to collective responsibilisation for promoting individual and collective interests in sustainable development. An essentialist approach that highlights certain basic characteristics is article 49 of the UN Guidelines for Consumer Protection which states that sustainable consumption 'includes meeting the needs of present and future generations for goods and services in ways that are economically, socially and environmentally sustainable'. In the performative and descriptive senses, sustainable development can be part of consumers' 'expressed preferences as "ethical"' subjects to other actors involved in making markets including state agents, corporations and regulatory agencies' (Barnett et al., 2011:85). Kysar (2005:641) similarly argued that consumers increasingly purchase 'not only products, but also shares of responsibility in the moral and ecological economy that produces them'.

Nonetheless, the existentialist approach to sustainable consumption seems to dominate scholarly and policy suggestions. The existentialist approach conveys the idea of individual consumption preferences and decisions coupled with individualised responsibility for promoting sustainable development. Evans et al (2017:3) noted that 'sustainable consumption is commonly thought to be premised on appeals to the responsibilities of consuming subjects.' This is succinctly illustrated by Shove's (2010:1274) ABC framework of 'attitude, behaviour and choice' which she observed 'is an indication of the extent to which responsibility for responding to climate change is thought to lie with individuals whose behavioural choices will make the difference'. While some share Shove's criticism of individualised responsibilisation (see Strengers and Maller, 2015), others have stressed the need to avoid moving 'too far in the 
other direction' (Whitmarsh et al., 2010:259) of exclusion of individual responsibility for sustainable responsibility.

The middle ground of shared responsibility between the sociological and the individualised approaches to sustainable development avoids governmental abdication of responsibilities for consumers while acknowledging that individual consumption and production patterns can make a meaningful impact. It incorporates the essentialist, existentialist and performative approaches to sustainable consumption and is reflective of the collective approach required for sustainable development. The reality is that sustainable consumption involves how 'one set of collective actors (campaigns, NGOs, charities) engage with other collective actors (retailers, suppliers, corporations) through the real and discursive figure of 'the ethical consumer' (Clarke et al., 2007: 238). There is also the private interest dimension suggesting the need to protect consumers' physical and mental wellbeing in utilising products and services as well as their personal interest in advancing sustainable development even when they may not be directly affected in the short or longer term. The dual protective dimensions are exemplified by article 18 of the World Health Organisation's Framework Convention on Tobacco Control (WHO FCTC) which reiterates the need for protecting 'the environment and the health of persons in relation to the environment in respect of tobacco cultivation and manufacture'.

Based on the shared responsibility approach to sustainable consumption, we draw on the SDGs to make the original argument that sustainable consumption and production is a multiconstituent concept that needs to be developed further and unbundled for greater clarity and effectiveness. We will therefore now proceed to demonstrate that the foundational elements of 'sustainable consumption and production' consist of: (a) sustainable consumption by proximate consumers for future generations; (b) sustainable production for future generations; (c) sustainable consumption by/for proximate consumers; (d) sustainable production for proximate consumers; (e) participation by proximate consumers; and (f) corporate social responsibility. 
The application of these underpinning elements in the developing country context completes an institutional septet for sustainable consumption and production as partly mapped out by the SDGs. The remaining part of this section explains these core elements in further detail.

\subsubsection{Sustainable consumption by proximate consumers for future generations}

This conveys the orthodox notion of sustainable consumption as requiring 'sustainable lifestyles' (Targets 4.7 and 12.8 of the SDGs). In several respects, the success of the sustainable development agenda can depend on the behaviour and lifestyle choices of individuals and groups (Shove, 2004), hence the recognition of the role of ethical consumption (Bray and Johns, 2011; Newholm et al, 2015). Some consumers favour 'green consumption' and refrain from purchasing products of unsustainable practices (Black, 2010). These 'ethical consumers' may be willing to pay higher prices. Consumers have, for instance, been known for paying more for 'fair trade' products even when cheaper alternatives are available (Castaldo et al, 2009; Andorfer and Liebe, 2015; Campbell et al, 2015). Although there are some doubts on whether purchasing decisions are always aligned with consumers' ethical orientations rather than price and other economic factors (Carrington et al, 2016), consumers are more likely to undertake ethical consumption when they feel that they can make a difference (Antonetti, and Maklan, 2014).

Unilever (2017) recently reported that about 33 percent of consumers prefer to purchase 'sustainable brands' based on their 'environmental and social impact'. The report estimated the global 'opportunity' value of 'sustainability credentials' to be $€ 966$ billion. Based on a fivecountry study, the report significantly noted that a greater proportion of consumers in emerging economies of India ( 88 percent), Brazil and Turkey (both 85 percent) were influenced by sustainable production than consumers in the more developed markets of the UK (53 percent) and US (78 percent). The attitudinal difference was attributed mainly to the direct impact of unsustainable practices on consumers and residents of emerging economies and the greater 
power of social norms that included sustainability scrutiny of purchasing decisions by family and friends of consumers in those countries.

\subsubsection{Sustainable production for future generations}

The critical role of production patterns is highlighted by various provisions of the SDGs (e.g. Targets 2.4, 12.2-12.6, 15.2). Regulations, fiscal incentives and other institutional factors can determine production patterns. For example, the Environmental Audit Committee of UK Parliament is investigating the environmental and social impact of the fashion industry (House of Commons, 2018). Specifically, the Committee is looking into the 'carbon, resource use and water footprint of clothing throughout its lifecycle' and the recycling of clothes and reduction of waste and pollution.

Nonetheless, consumption can potentially influence the cessation of unsustainable business practices and encourage innovation and adoption of more sustainable products and production methods. In 2003, an Indian nongovernmental organisation, Centre of Science and Environment reported that the pesticide content in samples of Coca Cola products being sold in the country far exceeded allowed in European countries (Bantekas, 2004; Hills and Welford, 2005; Burnett and Welford, 2007); Cedillo Torres et al, 2012). It also reported that Coca Cola was extracting a large quantity of underground water and was polluting water bodies in its production processes. In the immediate aftermath, the report led to significant reduction in consumer purchase of Coca Cola products in India and even the suspension of the products by some American universities. While it later denied the allegations in the report in its 2006 Corporate Responsibility Review, Coca Cola sought to demonstrate changes to its production methods (Altschuller et al, 2010).

While the Volkswagen emissions scandal could be examined by references to breaches of US legislation, the penalties imposed and the sustainable development implications of vehicle 
emissions for the future generations, there is the additional element of the interest of consumers in promoting sustainable production for the future generations. One of the triggers for the scandal was the apparent corporate mission to influence at all costs, including by false information, the sustainable development conscious consumers who would be willing to pay a premium for sustainable products and services. These consumers would actively refrain from the purchasing 'unsustainable' products especially when alternatives are available. Consumers are being encouraged by several institutional agents to tackle greenhouse gas emissions through reduced and alternative consumption (Cherrier et al, 2012).

\subsubsection{Sustainable consumption by/for proximate consumers}

It is sometimes in the consumer's own interest to engage in sustainable consumption. The interest can be material such as in saving money and resources through 'efficiency in consumption' (Target 8.4 SDGs) or refraining from 'wasteful consumption' (Target 12c SGS). Consumers can promote their physical and mental wellbeing by avoiding products such as tobacco. On this note, the SDGs' Target 3A requires the implementation of the WHO FCTC within the Goal 3 promise to 'ensure healthy lives and promote well-being for all at all ages.'

Consumers may also be affected even when the environment or the future generations are also affected. In Guerra v Italy, ${ }^{2}$ the European Court of Human Rights (ECHR) held that "severe environmental pollution may affect individuals' well-being and prevent them from enjoying their homes in such a way as to affect their private and family life adversely'.

Consumers require information capable of influencing their beliefs, intentions and attitudes (Longo et al, 2019) towards sustainable development and enabling them to make appropriate consumption and lifestyle choices. For example, in holding that a government failed in its duty

\footnotetext{
${ }^{2}$ Guerra v Italy (1998) 26 EHRR 357, [1998] ECHR 7 at [60].
} 
of informing local populations of environmental pollution risks, the ECHR noted that 'the applicants waited, right up until the production of fertilisers ceased in 1994, for essential information that would have enabled them to assess the risks they and their families might run if they continued to live at... a town particularly exposed to danger in the event of an accident at the factory.'3

\subsubsection{Sustainable production for proximate consumers}

While consumers can directly benefit from improvements in product quality and innovations that improve quality of life, some products can be harmful to their wellbeing. There are references in the SDGs (e.g. Targets 2.4, 3.5, 3.9, 3a) to confirm that products and production patterns should consider the wellbeing of proximate consumers. Tobacco is one example, prompting the EU Tobacco Products Directive 2014 and Directive 2001/37/EC which provide maximum tar, nicotine and carbon monoxide content of cigarettes for export. The content and quality of some products can make them potentially harmful to consumers. For instance, in Fijabi v Nigeria Bottling Company Plc, ${ }^{4}$ a franchisee of Coca Cola in Nigeria sold beverages containing benzoic acid preservative at levels the UK and other European countries declared unsafe for consumption. Sustainable development in this type of case requires changes to production processes.

The references to access and affordability in the SDGs (e.g. Targets 7.1, 11.2) show the need to protect proximate consumers' material interest. Inefficient products such as high-fuel consumption vehicles and production and methods can raise costs for proximate consumers. The introduction of carbon emissions vehicle taxes in the UK (HM Revenue and Customs, 2018) is an indication of direct consumer interest in sustainable development in that context.

\footnotetext{
${ }^{3}$ Guerra v Italy (1998) 26 EHRR 357, [1998] ECHR 7 at [60].

${ }^{4}$ Fijabi v Nigeria Bottling Company Plc Suit No. LD/13/2008 of 15 February 2017.
} 
Consumers also are financially affected when products are marketed in such ways to encourage inefficient use and waste. This is the backdrop to the WHO International Code of Marketing of Breastmilk Substitutes. Similarly, regulators like the UK Advertising Standards Authority have been acting against advertisements considered as socially irresponsible for encouraging, or appearing to promote, unsustainable and unhealthy consumer practices.

Consumers may be directly affected if laws of some jurisdictions prohibit certain products or impose extra financial burdens on consumers for using them. Bramhill v Edwards ${ }^{5}$ where a motorhome failed the UK size requirements after complying with the US rules suggest this possibility in cases of conflicts of sustainable development laws.

\subsubsection{Participation by proximate consumers}

The sustainable development agenda requires the inclusion and participation of key stakeholders like consumers. Inclusivity is one of the goals of sustainable development as evidenced by Targets $1.4,10.2$ and 10.3 of the SDGs. While Target 4.7 highlights the imperativeness of appropriate knowledge and skills for inclusivity, Targets 6b, 17.16 and 17.17 provide a linkage to stakeholder participation. The importance of stakeholder participation in environmental policy is highlighted by principle 23 of the World Charter for Nature $1982 .{ }^{6} \mathrm{~A}$ safe environment is linked to the 'rights' to health and participation in environmental decisions (Francioni, 1991:293). Similarly, some government agencies and international organisations have been promoting community participation in public health programmes. Falletti and Cunial's (2018) comparative study of Western Europe and Latin America identified monitoring

\footnotetext{
${ }^{5}$ Bramhill v Edwards [2004] EWCA Civ 403.

${ }^{6}$ World Charter for Nature adopted in General Assembly Resolution n.37/7 of 28 October 1982.
} 
and policy-making as the two forms of programmatic participation for the community stakeholder groups that could explain the two regions' relatively advanced social welfare systems.

Engagement in sustainable consumption is dependent on the consumers' knowledge in addition to their willingness to participate. Although consumers' purchasing decisions are often driven by their 'consumption knowledge' derived from experiences of product use (Clarkson et al, 2013), institutional agents can be influential in shaping new knowledge. In Guerra $v$ Italy, ${ }^{7}$ the European Court of Human Rights held that a government's failure to inform the host community of a 'high-risk' chemical factory and the details of the environmental pollution risks, constituted a breach of the residents' right to private and family lives. In other words, the government has a positive duty to identify, collect and disseminate information on relevant corporate activities.

\subsubsection{Corporate social responsibility}

While it is increasingly clear that a growing number of consumers have become sustainable development champions through their product purchasing decisions, consumption patterns and lifestyle choices, consumers are in a relatively weak position compared to corporations. In addition to determining production methods and processes, corporations enjoy knowledge advantage over consumers. Corporations have better access to scientific knowledge, technology and resources that can identify, track, monitor, evaluate and resolve sustainable development issues. If, according to Blake (1999:271), "the "public" is best defined in terms of alienation from dominant political or knowledge regimes in a particular context' then consumers are more likely than corporations to be regarded as such. Matters such as 'technical

\footnotetext{
${ }^{7}$ Guerra v Italy (1998) 26 EHRR 357, [1998] ECHR 7.
} 
assistance..., know-how..., product development..., and health and safety issues ${ }^{8}$ require 'superior knowledge'. This is applicable to proximate consumers and future generations who are potential harmed by victims of unsustainable activities.

The reality is also that corporations are not 'passive and powerless' (Anabtawi and Stout, 2008:1275.) in their relationship with state agents. There are several dimensions to corporate power. First, political institutions may be unwilling or unable to impose strong national standards or to demand the observance of international best practices from powerful private actors such as corporations. Secondly, corporations can interfere with formal regulatory processes and engage in 'regulatory capture' that results in weakened substantive rule and enforcement. The ability of tobacco companies to engage in 'dissuasive efforts' and political lobbying against effective regulations of the industry is noticeable even in a country like Switzerland (Maurisse, 2019). This, perhaps, explains why article 5.3 of the WHO FCTC demands the protection of public health policies from 'commercial and other vested interests of the tobacco industry'. Thirdly, economic actors such as multinational corporations are sometimes not incentivised, including by public and private sanctions, to adopt more sustainable practices even when they are aware of, and may in fact adhere to, such practices in the more advanced countries. This is also applicable to international law (de Jonge, 2011; Omoteso and Yusuf, 2017). Despite the reality that 'companies today operate across the globe through a complex web of subsidiaries and affiliate concerns' (Deva, 2012:4), international law seems to play a 'modest role in holding corporations to account' (van Dam, 2011:225). Soft law initiatives such as the UN Global Compact and OECD Guidelines for Multinational Enterprises (OECD, 2011) attempt to fill the gaps in international law with limited success.

\footnotetext{
${ }^{8}$ Chandler v Cape Plc [2012] EWCA CIV 52 [13-16] (Lady Justice Arden relied on these factors to impose a duty of care on a parent company over its subsidiary's employees).
} 
The emergence of the notion of CSR can be traced to these factors. CSR demonstrates that corporate obligations are not restricted to explicit legal provisions. CSR dictates that corporations should not abuse their knowledge and political power. Corporations are expected to apply their power and influence to address social issues and even undertake some traditional governmental functions (Osuji, 2015; Osuji and Obibuaku, 2016). Scherer and Palazo (2011) argued that corporations are political actors that are recognised as such by nongovernmental organisations who demand CSR, public governance roles and stakeholder engagement from them.

There exists an emergent evidence of consumers who are motivated by moral considerations (Andorfer and Liebe, 2013; Johnstone and Tan, 2015; Shaw et al, 2016; Perera et al, 2018) and are attracted by positive CSR credentials of a business or a product. Sustainable development is one of considerations, hence its advertisement as part of CSR can be a significant factor for consumer selection of products and services (Green and Peloza, 2014). Corporations are therefore increasingly expected by consumers and other stakeholders to engage in selfregulation of their operations, supply and purchasing chains while addressing sustainable development and other social issues. For example, the Greenpeace's 'Slaughtering the Amazon' campaign compelled Nike and Addidas to stop their operations and supply chains from using leather sourced from the Amazon (Bernd et al, 2016). The 'dirty fuel' movement challenged the 'fiction of clean hands' previously adopted by the European corporate and political institutions (Yoboué, and Kaufman, 2018:291). The CSR scheme, therefore, presume that corporations will refrain from exploiting 'institutional voids' (Karam and Jamali, 2013: Doh et al, 2015; Husted, 2015) triggered by public governance failures, especially in developing countries.

\subsubsection{Sustainable consumption and consumer protection}


This section has shown that, while corporations can promote sustainable development through CSR, consumers can play an institutional role in nudging corporations to adopt appropriate CSR. Consumers need to be aware of this responsibility, and there must be a suitable consumer protection approach, for sustainable development to be advanced through CSR, especially in the developing country context which this chapter examines next.

\subsection{Sustainable consumption in the institutional context of developing countries}

As noted above, developing countries can present challenges to adapting consumption for sustainable development due to possibilities of institutional voids. This section will show that institutional voids arise from the incapacity of formal institutions that lead to weak substantive standards; and from inadequate enforcement of consumer protection rules which in turn adversely affect the potential role of consumption in promoting sustainable development.

The institutional approach accentuates the role of geography and culture in the identification of institutional needs and structures, because it highlights how these factors can vary the success of sustainable development from country to country. Acemoglu et al (2005:399-402), for example, attributed geographical differences as one of the factors for the economic performance of countries. They give the examples of the impact of climate and the disease burden faced by a country, which can impact the productivity, behaviours and incentives of different actors within it. Under the factor of 'culture' and based on a field of anthropological research, they noted that some societies may become 'dysfunctional' because they have adopted a belief system or system of operating which does not promote the success or prosperity of the society. For example, the mentality in one country that public office is an opportunity to amass private wealth rather than correct societal ills is a factor that might 
influence the actions available to various institutional actors, such as consumers, in a way that differs in more developed countries.

Despite its global appeal, sustainable development, as underlined by the SDGs (e.g. Targets 3b-3d, 6a, 9.5, 9a, 11c and 12a), presents context-specific issues for developing countries. Some challenges confront consumption and its role in sustainable development in developing countries. While issues such as poverty, diseases and environmental factors that may require geography-specific solutions, the formal institutions may be incapable and even prone to exploitation by private and informal institutional actors like corporations. One is political and regulatory incapacity of political institutions as demonstrated by Fijabi v Nigeria Bottling Company $\mathrm{Plc},{ }^{9}$ where Nigerian regulators declined to even require warning labels for the benefit of consumers.

Similarly, Public Eye reported that Swiss companies sold extremely high sulphur content fuels to consumers in African countries (Guéniat et al, 2016). These high sulphur content fuels are toxic to human health and cause respiratory diseases and deaths, pollute the environment, and even impede economic development (WHO, 2006; World Bank, 2013). The companies profited from 'regulatory arbitrage' between the typically restrictive regulations of Europe and lax standards of African countries (UNEP, 2016). In response, the Centre for International Environmental Law (CIEL, 2017) argued that Belgium and the Netherlands were in breach of their international law obligations in allowing dirty fuel exports to African countries.

Another area of inconsistency of standards is tobacco. On the one hand, smoking had fallen by 38 percent in European countries mainly due to preventative public health campaigns, use policies and taxation-induced price increases (Maurisse, 2019). On the other hand, the number

\footnotetext{
${ }^{9}$ Fijabi v Nigeria Bottling Company Plc Suit No. LD/13/2008 of 15 February 2017.
} 
of smokers in African countries is steeply increasing and predicted to constitute about 40 percent of the continent's population by 2025 from the current levels of 6.5 percent. Tobaccoassociated deaths will be doubled by 2030.80 percent of smokers now reside in low- and middle-income countries. Public Eye reported the 'double standards' of Swiss tobacco companies in selling to African markets cigarettes that are more toxic than those sold and smoked in European countries (Maurisse, 2019). These companies were exploiting the fact that Switzerland, not being an EU member state, is not subject to tobacco product rules under Directive 2001/37/EC and allows cigarette content to be determined by the law of the importing country even when the law is weak or promotes unsustainable practices. In countries like Morocco, local authorities had no procedures and measures for investigating and monitoring the ingredients and toxicity of cigarettes.

The Volkswagen emissions scandal also epitomises the developed-developing countries divide. While the scandal has generated a furore among regulators and consumers in the advanced jurisdictions (Crête, 2016), the reaction in developing countries has been muted at best. This leads one to wonder whether Volkswagen vehicles were not sold in developing countries. In some developed jurisdictions, Volkswagen was penalised by regulators and compelled to recall millions of its vehicles for refitting and to compensate consumers. Consumers brought civil proceedings, including class actions in countries like the US. ${ }^{10}$ The EU initiated the Real Driving Emissions test to improve the reliability of emissions testing. The European Commission (2017) has been tightening regulations around the level and testing of vehicle emissions having acknowledged the impact on the environment and people's health and

\footnotetext{
${ }^{10}$ See People of the State of California v Volkswagen, 16-cv-03620 (2016); in re: Volkswagen 'Clean Diesel’ MDL 15-MD-2672-CRB (JSC).
} 
wellbeing, including linkages between pollutants and premature deaths and respiratory diseases.

The Volkswagen scandal highlight the sharp differences between developing and developed jurisdictions with regards to the consumer protection responsiveness of formal and informal institutions. While article 2(2) of the United Nations General Assembly Declaration on the Right to Development (1986) 'imposes' responsibility on all, including consumers and other individuals, the reality is that the awareness of this responsibility and the ability to take steps to enforce it differs between jurisdictions. The institutional theoretic model can attribute the jurisdictional differences to the capability of formal institutions such as consumer law, environmental law, legal system and administrative agencies and private institutional actors like consumers.

This is evident in other areas of business activity that potentially affects sustainable development and consumers such as gas flaring in Nigeria's Niger Delta which emits harmful gases linked to global climate change. The US Environmental Protection Agency's greenhouse gas calculator equated the emissions to driving 3.5 million passenger vehicles and annual operations of four coal-based power plants (Myles et al, 2018). The direct human impact includes lack of conversion for electricity especially in a country where power supply is scarce and erratic, heat and noise pollution, depleted wildlife scared by drastic changes to the environment, reduced farm yield, destruction of farmlands and deprivation of means of livelihood, deprivation of sleep due to perpetual bright light and hot environment, and contaminated water, reduced air quality, non-communicable diseases such as cancer and respiratory infections (Myles et al, 2018).

Although it was officially prohibited in 1984 by the Associated Gas Reinjection Act, gas flaring has persisted in Nigeria. A gradual reduction in the practice would be normally expected over 
time like in other gas flaring nations, but a recent investigation reported the reverse despite the government's cessation deadline (Myles et al, 2018). The World Bank's Global Gas Flaring Reduction Partnership (2018) ranked it sixth globally from the seventh position in 2017 and second in Africa in terms of gas flaring levels. Multinational oil companies often claim that they could not adopt more sustainable alternatives but curiously ceased gas flaring in the more advanced countries where they also operate. Stakeholders insist that Nigeria's latest 2020 deadline for ending gas flaring is unrealistic due to the government's lack of 'the willpower and sincerity to force the oil companies to use modern equipment' (Myles et al, 2018). Even the uncollected fines from the oil companies between April 2008 and October 2016 are estimated at $\$ 14.298$ billion (Myles et al, 2018).

The discussions in this section highlight the need to avoid reliance on formal (public) institutions in developing countries if the sustainable development agenda can be promoted through sustainable consumption and production. Furthermore, private institutional actors can facilitate sustainable consumption and production through the identification and enforcement of appropriate standards. These actors can play a more effective role when they are recognised by legal institutions as being vital for sustainable development.

\subsection{Septet framework and consumer protection for sustainable development}

The septet framework developed (above) here has clarified the inter-connectedness of sustainable consumption and production to the needs of present and future generations in the overall sustainable development agenda. While the institutional theory acknowledges the potential role of public and private institutions in promoting sustainable development, it is necessary to protect consumers' heterogenous needs and interests in view of the essential elements of sustainable consumption identified above. Although developing countries like 
Nigeria (Monye, 2018) tend to adopt models from developed jurisdictions due to shared colonial history, a context-specific approach to institutions is imperative as equally demonstrated by Target 16a of the SDGs. The task of this part is therefore to suggest an appropriate consumer protection model for sustainable consumption, especially in the developing country context. We outline below original arguments for a more interventionist approach that can support the septet approach to using sustainable consumption to promote sustainable development.

\subsubsection{Consumer protection law}

While the six foundational elements of the septet framework show that sustainable consumption and production may be pursued for consumers' interest and for the common good, including future generations, the law as an institution has a vital role to play in protecting consumers' role in the consumption chain. Two approaches to protecting consumers through the law can be identified: consumer law and consumer protection law. A key difference between the consumer protection law and consumer law approaches is the latter's individualistic emphasis on consumers' ability to make, and enforce their, free, rational choice (Huffman, 2010:11). In other words, consumer law focuses on information provision at the pre-contractual stage of transactions. The assumption is that consumers need information about different choices (Akinbami, 2011:135) and, if this is available, consumers will make the right or 'rational' choice that promotes market efficiency (Spindler, 2011:317). Consequently, it is more information focused and less interventionist than a consumer protection law approach.

Having shown the relative vulnerability of consumers with respect to the cardinal components of sustainable consumption, we propose a 'consumer protection' approach. The consumer protection approach regards consumers as weaker parties and addresses market failures that impede consumers' ability to maximise their welfare (Huffman, 2010). It uses regulations to protect their interests at the transactional level in a three-fold manner. First, consumers may be 
protected against businesses to prevent the latter's unscrupulous or exploitative activities (Inderst, 2009). Secondly, the consumer protection approach can apply a degree of paternalism to protect consumers from self-harm. An example is when consumers are protected against taking excessive credit and financial risks (Bar-Gill and Warren, 2008; Gerding, 2009). Thirdly, unlike competition law and other areas of law which rely on administrative enforcement to protect consumers at the macro level, consumer protection provides consumers with private law rights (Huffman, 2010).

Consumer vulnerability therefore seems essential to the consumer protection law approach. The concept of 'vulnerable consumers' is well-known in EU instruments which protect individuals on the basis of age, mental or physical infirmity or credulity. ${ }^{11}$ This is, however, criticised for linking the concept to the notion of 'average consumer' and using individual consumer characteristics in the determination of business liability (Incardona and Poncibo, 2007). In contrast, the situational approach to consumer vulnerability canvassed in this chapter reflects consumers' limited knowledge and powers that even a consumer strongly desires to advance sustainable protection. The situational approach is supported by Buet which suggested vulnerability as a question of circumstances. The ECJ stated that, being that they are more likely to be behind on their education and wish to catch up and enhance their job prospects customers of door-to-door educational enrolment salespersons may be more vulnerable and

${ }^{11}$ Council Directive 2005/29/EC of 11 May 2005 concerning unfair business-to-consumer commercial practices in the internal market and amending Council Directive 84/450/EEC, Directives 97/7/EC, 98/27/EC and 2002/65/EC of the European Parliament and of the Council and Regulation (EC) No 2006/2004 of the European Parliament and of the Council ('Unfair Commercial Practices Directive') [2005] OJ L149/27, art 5(3). 
open to sales tactics than consumers in most canvassing situations. ${ }^{12}$ The court also stated that, because the provision of education is not a consumer service/product to be used daily, a poorly considered purchase could cause the buyer more long-lasting harm than mere financial losses, including low quality or unsuitable training that could harm job and training prospects. ${ }^{13}$

\subsubsection{Interventionist consumer protection}

While, the consumer protection law approach is a spectrum of interventionism, here, as noted in the introduction, it is argued that a more interventionist consumer protection law approach of a mix of recognition of consumer vulnerabilities, consumer private law rights, and stakeholder rights and responsibilities to complement administrative enforcement, is useful for sustainable consumption. According to Llewelyn (1999), 'the concept of "protecting the consumer" is largely protection against the costs of externalities and other market imperfections and failures.' Similarly, a non-interventionist approach to consumer protection will not advance sustainable development which often reflects ethical and selfless goals sometimes for the common good of society and often for protecting future generations. This is evident from the common pool resources studies (Gabaldon and Gröschl, 2015) which reference moral justifications for sustainable development obligations of members of society that may be irrelevant factors for non-interventionism. Non-interventionist approaches are favoured by economists (La Porta et al, 1999) and reflect capitalist orientations (see Baldwin et al, 2012). While it gives self-interest a preeminent position and allows little room for morality in the market, pure capitalism can clash with ethical ideals when economic and social actors are confronted by certain matters of society. This was illustrated by the cases of

${ }^{12}$ Case 382/87 R Buet and Educational Business Services (EBS) V Ministère Public [1989] ECR 1235, para 13.

13 ibid, para 14. 
irresponsible lending where the pursuit of profit and personal rewards drove lenders to ignore affordability, consumer needs and other matters that would protect consumers and financial stability (Osuji, 2017).

Norbert Reich (1992) identified 'pre-interventionist', 'interventionist' and 'postinterventionist' philosophies as the broad approaches to consumer protection. Preinterventionist approaches developed from commercial and competition law and incorporates basic assumptions of civil law like caveat emptor and freedom of contract and provides limited solutions by refraining from imposing specific standards on contractual relations. Regarding information as a key component of consumer autonomy, it promotes improved consumer autonomy through self-help information systems and government-monitored information systems like labelling. The interventionist or regulatory approach reflects a more active role for the state in social relations encapsulated in the notion of the 'welfare state'. Under the approach, the welfare state can control and modify traditional principles of freedom of contract, caveat emptor, competition and fault liability that might be unfavourable to consumers. This is complemented by welfare economic theories dealing with the power aspects of market transactions and re-establishment of bargaining power through tools like warranties and restricting exemption clauses.

The post-interventionist approach is a middle ground between interventionism and preinterventionism. It promotes 'mixed rationality' (Reich, 1992:267) using tools such as product liability for businesses in addition to labelling, instructions and warnings requirements in favour of consumers. Advocate-General Geelhoed implicitly referenced the postinterventionist by stating that

before acquiring a given product (for the first time), a consumer will always take note of the information on the label and that he is also able to assess the value of that 
information. [A] consumer is sufficiently protected if he is safeguarded from misleading information on products and that he does not need to be shielded from information whose usefulness with regard to the acquisition and use of a product he can himself appraise. ${ }^{14}$

The post-interventionist approach explains the gradual shift in EU consumer policy from consumer protection to consumer law. The focus shifted from protecting the weak consumer to the 'average consumer' (Micklitz, 2012, 2013) except in certain cases of situational vulnerability such as door-to-door selling. Micklitz (2013) criticised the average consumer approach and highlighted four classes of consumer: informed consumers; responsible consumers that can make use of information provided to exercise their rights; circumspect consumers that benefit from market-rectifying mechanisms that grant minimum levels of fairness through mandatory rules; and vulnerable consumers that require the protection of the legal system and can be afforded status-based antidiscrimination and social justice rules. Micklitz (2013) therefore proposed a 'mobile system of rules' and 'conceptual descriptions' that assigns rights and obligations to different classes of consumer.

The differentiated consumer class and remedies approach highlights the fact that consumers are not homogenous and can include vulnerability-based differentiation. Consumer vulnerability is relative to other market participants (Cartwright, 2011). Consumers may be vulnerable in comparison to other market players like traders or in comparison to other consumer groups. Consumers may have the capacity to look after their own interests but still relatively vulnerable or disadvantaged (Cartwright, 2011). Sustainable consumption can be contextualised in this relative vulnerability or disadvantage by providing a less information-

\footnotetext{
${ }^{14}$ Case C-239/02 Douwe Egberts NV V Westrom Pharma NV and Christophe Souranis, opinion of Advocate General Geelhoed of 11December 2003, [54].
} 
focused approach to empowering the consumer institution in relation to the varied vulnerabilities of consumers and their institutional environment.

\subsubsection{Beyond disclosure}

While participation by proximate consumers and other foundational elements of the septet framework suggest the importance of information availability to consumers, we are demonstrating that the more interventionist consumer protection law approach required for sustainable consumption and production shows that disclosure should not be the focus of regulatory interventions in aid of sustainable development. The role of disclosure regulation in consumer protection is debated (see Howells, 2005; Ben-Shahar, 2009; Nield, 2010; Domurath, 2013; Fejos, 2015; Gardner, 2017; Overton and Fox, 2018; Willett, 2018) within the broader debate on regulatory approaches. Regarding securities regulation, for example, some economists have identified possible alternative regulatory approaches by government through the 'three broad hypotheses' of the 'alternative theories of optimal legal arrangements' (La Porta et al, 2006:1). First, the 'null hypothesis' (Coase (1960, 1975; Stigler, 1964) is against governmental regulation of any form. The argument is rather than in favour of market regulation by private market participants such as investors and stock exchanges who can require and rely on quality disclosure. The market participants can enforce rules and standards through reputation incentives and private legal proceedings based on contract law and tort law. Secondly, economists like Easterbrook and Fischel (1984), having noted the expensive and unpredictable nature of private litigation promoted by the null hypothesis, support government's role in providing standard (model) contracts for market participants which can reduce the costs of private contracting and enforcement and promote certainty of rights and obligations. This school supports governmental disclosure regulation that specifies what to disclosure and liability for non-disclosure or defective disclosure. In contrast to the liberal framework of the other two, the third approach supports regulation by state agents and 
perceives private market regulation as relatively weak (Landis, 1938; Polinsky and Shavell, 2000; Glaeser and Shleifer, 2003). Public regulators such as the US Securities and Exchange Commission are favoured over private regulation due to their relative independence, detachment from political interference, and the abilities to provide binding regulations, seek and obtain information and impose sanctions on market participants.

The 'rational choice theory' of consumers in the information paradigm, for example, informed articles 3, 4, 5 and 6 of the Distance Marketing Directive 2002 of the European Commission. As Howells (2005) however detailed, the information paradigm has several weaknesses. These include the assumption of clarity of information to, and its understanding by, consumers and consumers' tendency to ignore information provided. In addition, disclosure regulation can ignore the imbalance in the business-consumer relationship, including the fact that businesses can limit the effectiveness of information through marketing activities that exploit consumer information weaknesses. Akinbami (2011:135) similarly noted that businesses can 'exploit an unfair advantage they have over their consumers in terms of superior information and expertise'. Businesses can apply 'heuristics' that 'results in cognitive weaknesses in individuals' decision-making, leading them to make inferior decisions with regard to their welfare' (Akinbami, 2011:144). Consequently, the European Union appeared to have been adopting a more interventionist approach rather than exclusive reliance on disclosure regulation in financial consumer law, for example (Cherednychenko, 2010).

One of the consequences of the 2008 financial crisis is a growing realisation of the limited impact of disclosure as an exclusive regulatory method to support business-to-consumer contracting (see Nield, 2010; Osuji, 2017; Aldohni, 2017). As Akinbami (2011:136) observed, the financial crisis demonstrated that the information paradigm of the non-interventionist approach has 'little correspondence with the real world'. The financial crisis, which was partly 
triggered by consumer over-indebtedness, also created unprecedented levels of consumer debt in several jurisdictions. The OECD (2009) in a Draft Recommendation observed that '[o]ne of the features of the financial crisis is the emergence of inadequately regulated alternatives to traditional credit products, which have exposed vulnerable consumers to unsuitable offers, unfair sales practices, and the purchase of credit products that were clearly inappropriate for them.' One of the fallouts of the crisis was the acknowledgment by the then UK Financial Services Authority (FSA, 2009: para.6.12) of the need for the law to 'protect consumers from themselves' while the Treasury department stressed that 'every effort must be made to help consumers get the products that are right for their needs and circumstances' (HM Treasury, 2009: para.8.51).

Consequently, the UK appears to have adopted a more interventionist approach to regulating responsible consumer lending. In this regard, the Treasury Department (HM Treasury, 2011: para.4.17) explained that regulatory approach 'reflects the fact that different consumers require different degrees of protection, depending on their capability and personal circumstances, the product they are buying, and the channel through which they are buying it' (see also HM Treasury, 2012: paras.4.11-4.12 for similar comments). This is a form of paternalism which recognises that 'consumers can, and do make inferior decisions with regards to their welfare decisions' (Akinbami, 2011:136) and proceeds by 'using regulatory power over consumers for their own good' (Fairweather et al, 2017:3). In addition to the Unfair Commercial Practices Directive 2005, ${ }^{15}$ recital 3 of the Mortgage Credit Directive 2014 and recitals 3, 4, 5 and 6 of

15 Directive 2005/29/EC of the European Parliament and of the Council of 11 May 2005 concerning unfair business-to-consumer commercial practices in the internal market and amending Council Directive 84/450/EEC, Directives 97/7/EC, 98/27/EC and 2002/65/EC of 
the Payment Systems Directive 2015 show, the European Commission has similarly adopted a pro-interventionist approach to financial consumer regulation following the 2008 financial crisis.

These examples show that the rational choice theory basis of information regulation 'will not work for all markets and all consumers all of the time or in all situations' (Akinbami, 2011:136). Libertarianism favours disclosure as a regulatory tool to make consumers to make informed choices. It proceeds on the basis that consumers as 'rational economic creatures' can 'maximise their own self-interests' having 'had complete information, unlimited cognitive abilities and unlimited self-control' to make decisions (Akinbami, 2011:135, 136). In sustainable consumption, however, consumers may not be able to protect themselves from selfharm and external harm as demonstrated above. Consumers may also have collective interest and even altruistic goals for future generations to consider as institutional agents. This weakens the private contract and private interest basis of the rational choice theory and requires disclosure to be complemented by other regulatory tools.

\subsubsection{Beyond private contract law}

The libertarian school frowns at state intervention with 'limited, if any, regulation or other government intervention' (Akinbami, 2011:136). It supports private contract law as the basis for determining the parties' rights and obligations in business-to-consumer cases. The private contract approach of resolution of rights and obligations is highlighted by the statement of the Privy Council in MacLeod v MacLeod, ${ }^{16}$ albeit in relation to spousal agreements and financial

the European Parliament and of the Council and Regulation (EC) No 2006/2004 of the European Parliament and of the Council, OJ L 149, 22-39.

${ }^{16}$ MacLeod v MacLeod [2008] UKPC 64, [2010] 1 AC 298, [42] (Baroness Hale) (noted by Miles, 2009). 
consequences of divorce, that ' $[\mathrm{w}] \mathrm{e}$ must assume that each party to a properly negotiated agreement is a grown up and able to look after him- or herself.' Notwithstanding Kronman's (1980:473) contention that 'contractual regulation as a method of redistribution', the doctrines of privity of contract and consent (Hevia, 2013) and its 'unreflective understanding of the moral and political significance of contract' (Lucy, 1989:132) demonstrates traditional contract law's private transactional nature. It is founded 'upon a platform of neutrality with respect to distributive outcomes' (Collins, 1992:49). Damages award is normally based on inter-party considerations and not reference to outcomes on society. ${ }^{17}$

Nonetheless, a corollary to the interventionist approach to sustainable consumption is the recognition of distributive justice as a contract law goal. This requires a shift from the common law's traditional emphasis on corrective justice between contractual parties. ${ }^{18} \mathrm{~A}$ a distributive justice re-framed contract law can consider different segments of society in its outcomes rather than focusing exclusively on contractual parties (Collins, 1992). This enables a regulated contract law to be used to undertake institutional and public governance functions by imposing predetermined distributive justice goals and outcomes on privately arranged contracts. For example, a duty of care can also be imposed in certain circumstances to promote sustainable consumption. If a duty of care is imposed, it may be possible to impose responsibility for and provide accountability towards primary (proximate consumers) and secondary (future generations) victims of unsustainable practices. For example, in Rabone v Pennine Care NHS

${ }^{17}$ See Golden Strait Corp v. Nippon Yusen Kubishika Kaisha, the Golden Victory [2007] UKHL 12.

${ }^{18}$ For discussions of the corrective and distributive goals of contract law, see Kronman, 1980; Colins, 1992, 2004; Miller, 2013; Fejos (2018); Hardy et al, 2018. 
Trust, a patient who was discharged by the defendant hospital as inpatient committed suicide shortly afterwards. The UK Supreme court held that the hospital was in breach of its primary duty of care to the deceased as well as its secondary duty of care to the deceased's parents, noting that ' $[\mathrm{t}]$ he agony may be made worse by knowing that the loss both could and should have been prevented. ${ }^{, 19}$

\subsubsection{Resolving information asymmetry}

Although disclosure-focused regulation may be inadequate for sustainable consumption and production, this does not mean that that disclosure has no role in the septet framework. An interventionist approach in the septet framework requires improvements to consumer access to information even within a contractual framework. This requires that disclosure should be regarded as one of the ingredients of substantive regulation and not the exclusive regulatory tool. Better and effective information is also important in that it must be useful for consumers in their diverse role in promoting sustainable consumption. Consumers are unlikely to have access to superior information in contrast to businesses. The Volkswagen emissions scandal highlighted the information asymmetry between businesses (as manufacturers, distributors, retailers or service providers) and consumers in relation to sustainable development when proximate consumers or future generations are potentially victims of unsustainable practices. Consumers generally must rely on the information provided by businesses in making purchasing decisions and are often not able to verify such information in advance and postpurchase. As Lord Wright observed in a different context 'the reliance will be in general

${ }^{19}$ Rabone v Pennine Care NHS Trust [2012] UKSC 2 (SC) para.92 (Baroness Hale). 
inferred from the fact that a buyer goes to the shop in confidence that the trades man has selected his stock with skill and judgement. ${ }^{20}$

The sustainable development agenda can be promoted when counterparties to consumers are required to disclosure certain information related to production, marketing and distribution and business relationships involved in those processes. It may help if the disclosure duty is coupled with consequences for non-disclosure. For example, in Plevin v Paragon, ${ }^{21}$ the UK Supreme Court held that consumers were entitled to recover compensation from banks that failed to disclose commissions in payment insurance contracts they persuaded consumers to take up. A legal duty of this kind can facilitate the disclosure of information consumers may need to be effective institutional champions for sustainable development.

Timely availability of information to consumers is necessary since the courts may not award remedies if 'undue delay' or 'prejudice to third parties and good administration'22 occurs even when there are valid grounds for making challenges. For example, while consumers can theoretically promote sustainable development through appropriate positive and negative covenants, they need to be aware of the covenant's prospective and retrospective implications. Generally, contractual parties' ability to police covenants through mandatory and prohibitory injunctions depends on their awareness of the factual and legal circumstances. In Tabcorp Holdings $v$ Bowen Investments, for instance, a tenant in contumelious disregard of the landlord's rights ${ }^{23}$ secretly replaced an existing structure on the leased commercial premises.

\footnotetext{
${ }^{20}$ Grant v Australian Knitting Mills Ltd [1936] AC 85.

${ }^{21}$ Plevin v Paragon Personal Finance Ltd [2014] UKSC 61.

${ }^{22}$ Whitstable Society v Canterbury City Council [2017] EWHC 254 [76] (Admin) [129] (Dove J).
}

${ }^{23}$ Tabcorp Holdings Ltd v Bowen Investments Pty Ltd (2009) 83 ALJR 390, para.4. 
This was in breach of the leasehold negative covenant prohibiting alterations to the premises without the landlord's consent. Due to lack of knowledge, the landlord could not seek and obtain a prohibitory injunction against the tenant and was restricted to an award of damages. Contract law can therefore be reshaped to impose disclosure obligations and expand the range of remedies that can prevent surreptitious breach of sustainable development covenants and allow parties to insist on steps to redress unsustainable practices.

\subsubsection{Improving corporate social reporting for sustainable consumption-promoting CSR}

As discussed in relation to the sixth foundational element of the septet framework, CSR can be linked to sustainable consumption and production. The role of consumers and other stakeholders in using CSR to advance sustainable development is often tied to the quality of CSR reporting, which can be voluntary and mandatory. Reporting of corporate social activities is growing due to the popularity of CSR and the need to promote positive reputation that reflect the expectations of stakeholders like consumers (Osuji, 2012; Osuji and Obibuaku, 2016). As the UK Department for Business, Innovation and Skills noted, this type of reporting can promote transparency and corporate accountability (DBIS, 2010). Nonetheless, being that consumers increasingly rely on corporate social disclosures, which include information on sustainable development policies and practices, to make purchasing decisions, it is problematic when such disclosures lack credibility or are misleading. For example, the Deepwater oil spillage showed that BP's previous positive reputation for environmental protection and CSR generally was unearned (Balmer et al, 2011). When there is a 'dichotomy' (Osuji, 2011) between corporate disclosures and performance, consumers will be unable to play an institutional regulatory role for the promotion of sustainable development. To fill this gap, it may be useful to explicitly provide for private law rights for individual consumers and stakeholder organisations to challenge false or misleading reports. A consumer relied on such 
statutory provisions in a Californian statute in Kasky $v$ Nike ${ }^{24}$ case but that right was removed in an amendment to the law.

Another source of influence on the purchasing decisions of socially-conscious consumers is certification or ecolabelling. Certification can be provided by individual corporations, business associations or by third parties such as government agencies and independent nongovernmental organisations. Research suggests that consumers are more inclined to trust third party certification schemes (Darnall et al, 2018). Therefore, it is helpful for the sustainable development agenda to promote credible independent third-party certification schemes.

Sustainable consumption can play a more effective role when corporate social reporting and certification are linked to corporate performance. Improved credibility of sustainable development-related reporting can compel businesses, especially the consumer-facing ones, to promote it throughout their operations, supply and purchasing chains. This relates back to the concept of CSR the practice of which suggests that it is possible for a business to exercise some due diligence responsibility over legally separate entities and business partners. For example, Nike and Levis-Strauss were compelled by consumer and stakeholder pressure to monitor the labour standards of their supply chains and to voluntarily disclose their suppliers' factories to independent organisations to undertake verifications (Doorey, 2011). This trend is somewhat reflected in the emergent disclosure obligations of anti-modern slavery legislations of the UK, Australia and California, USA.

${ }^{24}$ Kasky v Nike 27 Cal. 4th 939, 946, 45 P.3d 243, 247, 119 Cal. Rptr.2d 296 (Cal. 2002), 123 S. Ct. 2554 (2003). 


\subsubsection{Consumer responsibilisation}

We have already shown that the sixth essential component of sustainable consumption in the septet framework is participation by proximate consumers. Although this involves the recognition of consumers as institutional agents for sustainable development, it is important to demonstrate the level of consumer engagement and participation for the interventionist approach required in the septet framework.

There are two models of engaging the public in public interest matters like sustainable development. These are the rationalist or information deficit and the deliberative or civic models which respectively appeal to passive and active participation (Owens, 2000). As discussed above, the rationalist approach is unsuitable for sustainable consumption due to the combined elements of self-interest, collective interest and altruism. The deliberative model can assist consumers in their interaction with other private and public institutional actors. For example, the UK courts have stressed the need for 'a conscious deliberative process ${ }^{25}$ in land use and development cases which requires local councils to comply with formal statutory mechanisms and consider expert and stakeholder evidence before reaching decisions. ${ }^{26}$

${ }^{25} R$ (on the application of Goodman) $v$ Secretary of State for Local Government \& Rural Affairs [2015] EWHC 2576 (Admin) [29] (Dove J).

${ }^{26}$ See $R$ (Midlands Co-operative Society Ltd) v Birmingham City Council [2012] LGR 393 [122-123]; Western Power Distribution Investments Limited v Cardiff City Council [2013] EWHC 1407 (Burton J); R (on the application of Goodman) v Secretary of State for Local Government \& Rural Affairs [2015] EWHC 2576 (Admin) (Dove J); Faraday Development Limited v West Berkshire [2016] EWHC 2166 (Holgate J); Whitstable Society v Canterbury City Council [2017] EWHC 254 [76] (Admin) (Dove J). 
Nonetheless, there should be mechanisms for raising consumer awareness of relevant issues and rationalisations for participation and prevent reticence to sustainable consumption. Eckhardt et al (2010) highlighted three rationalisations for consumer resistance to ethical consumption. The economical rationalisation is when price and other economic factors trump consumers' ethical orientations while institutional dependency is consumers' belief that ethical product regulation is government's sole responsibility. Development realism is the belief that unethical and unsustainable product development is a necessary component of national or macroeconomic development.

Consumers' participation therefore requires their 'responsibilisation' for sustainable development. To responsibilise consumers is to enhance their awareness of their own responsibility for the nature and consequences of their decisions and their role in resolving problems (Shamir, 2008). When couched in the economic sense of 'empowerment' responsibilisation reduces barriers to consumers' market participation and access to key information (Williams, 2007). Responsibilisation can be undertaken through consumer education and helps to improve consumer decision-making skills and ability to benefit from disclosure and other remedies. Nonetheless, when responsibilisation is designed to empower consumers to seek private means of protecting their interests, it can encourage individualism and erode solidarity in social policy (Williams, 2007). It may not address public and collective goods issues and the need for collective information and action (Kidd Jr and Daughtrey Jr, 2000:224).

The rationalist responsibilisation model of individual empowerment is therefore inappropriate for sustainable development. As discussed, sustainable consumption, from consumers' perspective, is not only about protecting the individual proximate consumer's interest and may seek to protect future generations. Furthermore, the rationalist model does not allow institutional and stakeholder perspectives which are necessary for promoting sustainable 
development. The 'emergent sense of distributed responsibility' (Evans et al, 2017:9-10) therefore offers a better alternative and follows the shared responsibility approach highlighted by article 50 of the UN Guidelines for Consumer Protection. Distributed responsibility also suggests the need for the participation of all segments of society and prevents key actors like governments abdicating their own responsibility for consumers. Similarly, OECD's Draft Recommendation on consumer credit (OECD, 2009) 'calls for a balanced policy focus on financial education and consumer protection, and reinforces the importance of financial literacy as a necessary complement to (rather than a substitute for) a sound framework for financial market regulation and prudential supervision.' The principles the Draft Recommendation encapsulates are applicable to other areas where it is desired that consumers should be active role in addressing issues they raise.

\subsubsection{Stakeholder rights and obligations}

Two strands of the more interventionist consumer protection we have argued here are the need for consumer private law rights and the need for recognising other stakeholder rights and responsibilities. The concept of sustainable consumption as unpacked by the septet demonstrate that consumers are a stakeholder group for sustainable development in line with Freeman's (1984:46) popular definition of 'stakeholder' as 'any group or individual who can affect or is affected by the achievement of the organisation's objectives'. The definition further suggests that consumers are not only stakeholder group for sustainable development and the discussions so far implicitly show that governments and corporations are equally stakeholders among others. While the dynamic nature of the concept of stakeholder (Miles, 2017) makes it adaptable to different contexts, what it means for sustainable development needs to be unpacked. The first issue is the identity of relevant stakeholders Fassin's (2009) analysis of the stakeholder model is helpful here. Fassin identified three classes of stakeholders: (real) stakeholders like consumers that are directly affected by corporate actions; stakewatchers like 
pressure groups and nongovernmental organisations; and stakekeepers who are regulators that enforce formal rules. These classes of stakeholder can play different roles in promoting sustainable consumption and production within the septet framework.

Following the identification and classification of stakeholders, the next issue is therefore whether they have or can have legal rights or obligations within the septet framework. In this regard, public interest organisations and other independent stakeholder groups play a multifaceted role in promoting the public interest as shown, for example, by the Kasky case. Following its 1990s sweatshop scandal, Nike agreed to independent verification of its suppliers' factories to ensure compliance with international best practices (Osuji, 2012). In aftermath of its 2003 Indian scandal, Coca Cola engaged local and international nongovernmental organisations in addressing the water usage issues and to restore consumer and public trust (Altschuller et al, 2010). Nike and Coca Cola experiences are instructive although the involvement of independent organisations was not backed by law. The legitimacy of these stakewatchers to act as claimants and interveners in public interest cases on behalf of consumers can be recognised by the law and public authorities. Independent organisations can promote legal accountability by representing and demanding protecting of the rights of stakeholders who may not have appropriate knowledge and resources.

Generally, enforcement of rules and standards can be carried out by public agencies or by private market participants if legally permitted to so do (Coffee, 2007; Jackson and Roe, 2009). Nonetheless, the relative competence of public authorities in developed jurisdictions like UK and EU suggest their reliance on administrative procedures. Experiences from consumer law and other fields of public interest also suggest the need to avoid relying exclusively on public enforcement. For example, having argued that the anti-corruption efforts of public agencies 
achieved modest success at best, Heilbrunn (2004:3) asserted the need to 'forge broad coalitions that can endure efforts of an organized opposition if they hope to succeed in the fight against corruption'. Similarly, the need for 'partnerships' of stakeholders cutting across individual firms, industries and sectors of society is increasingly being recognised in environmental protection policy and scholarship (Stadler and Lin, 2019).

The stakeholder enforcement approach can apply to corporations as well. If corporations are legally recognised as direct or indirect stakewatchers, a business may be required to ensure that its supply and purchasing chains reflect the best consumer protection practices, including in the provision of sustainable development-related information. For example, in Argos v Leather Trade House Ltd, ${ }^{27}$ the English High Court held that a furniture supplier must reimburse two retailers for millions of pounds in compensation they paid to consumers. While the supplier had assured the retailers that an anti-mould chemical in its products had no adverse effect on human health, consumers complained of skin irritation and respiratory problems. In Webster $v$ Liddington, ${ }^{28}$ the defendant doctors' brochure contained drug information supplied by its manufacturers. The doctors were held to have committed misrepresentation when it was found that the information excluded the side effects.

Corporate insiders, like employees, can act as sustainable development stakewatchers but they may be open to reprisals when they report wrongdoings. Whistleblowing protection is therefore necessary to encourage corporate insiders to disclose wrongdoings, unethical policies and

${ }^{27}$ Argos Ltd \& Others v Leather Trade House Ltd (formerly BLC Leather Technology Centre Ltd) [2012] EWHC 1348 (QB).

${ }^{28}$ Webster and others v Liddington and others [2014] EWCA Civ 560. 
practices to appropriate persons within and outside the organisation. A recent example of whistleblowing as a regulatory tool is the CRR Firms: Whistleblowing Amendment Instrument 2018 of the UK Prudential Financial Authority. A whistleblowing policy can make use of appropriate financial incentives to incentivise stakewatchers in making disclosures. The use of financial incentives to encourage whistleblowing is gaining traction although some jurisdictions like the UK are reluctant to adopt the approach. In contrast, the US the DoddFrank Wall Street Reform and Consumer Protection Act 2010 permits the transfer of a percentage of financial penalties paid by wrongdoers to whistle-blowers who facilitated the investigation and detection of misconduct (Laming, 2017).

\subsubsection{Independent determination of standards}

A particular example of the recognition of stakeholder rights and responsibilities in the more interventionist consumer protection approach of the septet framework is the legal provision for an independent stakeholder determination of sustainable development standards. In contrast, the courts composed of mainly legally qualified judges may not be able to determine, in an effective way, some technical issues surrounding sustainable development, especially as it applies to sustainable consumption and sustainable production. There may not be courts with specific jurisdiction for sustainable development and, even when there are consumer courts, the judges may not be specially trained in the diverse and often complex issues.

The expert stakeholder determination of appropriate standards is similar to some commercial dispute resolution practices that provide for third party experts to make binding decisions for parties. Expert determination has been applied in historical and contemporary commercial 
dispute resolution regarding issues such as product quality and product price. ${ }^{29}$ Traditionally, contract law permits parties to provide for third party determination of contractual terms despite the fundamental rule that contractual terms need to be clear and certain to be enforceable. ${ }^{30}$ Nonetheless, unlike commercial dispute resolution where expert determination of technical and factual issues is usually based on the parties' prior agreement that defines the issues to be addressed, ${ }^{31}$ the stakeholder determination in consumer protection can be imposed by law.

\subsubsection{Recognising 'agency problem' in sustainable consumption}

As discussed, one of the central features of the more interventionist approach in the septet framework is the recognition of stakeholder rights and responsibilities. We argue here that this requires the acknowledgement of the agency problem as a result of conflicts of interests in the consumption chain and its resolution through the application of the stakeholder model. Furthermore, corporate governance needs to be aligned with the stakeholder model in order to advance sustainable development through sustainable consumption and production.

The sustainable consumption chain includes manufacturers and their operations, supply and purchasing chains, distributors, retailers and consumers. Consumers can be differentiated from the others in the motivation, power and control of product and service quality. Unlike

${ }^{29}$ Nigel Blackaby et al, Redfern and Hunter on International Arbitration (6th edn, Oxford University Press 2015) 4.

${ }^{30}$ See Foley v Classique Coaches [1934] 2 KB 1; Sudbrook Trading Estate Ltd v Eggleton [1983] 1 AC 444, [1982] 3 WLR 315; Jacobs UK Ltd v Skidmore Owings \& Merrill LLP [2012] EWHC 3293 (TCC).

${ }^{31}$ Portland General Electrical Co. v U.S. Bank Trust National Association, 218 F.3d 1085, 1090) 9th Circuit 2000). 
consumers that may be driven by personal needs and tastes, businesses on the sustainable consumption chain are usually profit-motivated and able to prospectively bargain on, and determine, the production processes and outcomes. Therefore, a conflict of interests potentially exists between consumers and businesses on the sustainable consumption chain.

The need for the resolution of conflicts of interests is implicit in Adam Smith's statement in Wealth of Nations (1776: para.V.1.107) that company directors 'being the managers rather of other people's money than of their own, it cannot be well expected that they should watch over it with the same anxious vigilance'. This statement is often referenced in corporate governance discourse, specifically the separation of ownership and control of companies (Berle and Means, 1991), to illustrate the 'agency problem'. The agency theory has emerged to propose measures for reducing opportunities for conflicts of interests and to align the interests of 'agents' (often corporate directors and managers) as closely as possible to those of the principals (usually identified by economists as the shareholders). According to the agency theory there are three levels of conflict of interest in a business context (Jensen and Meckling, 1976; Armour et al, 2017). First, the classic case highlighted by Adam Smith is the conflict of interests between corporate directors and managers on the one hand and shareholders on the other hand (Enriques et al, 2017a). Secondly, it has been recognised that a conflict of interests exists between majority shareholders and minority shareholders (Enriques et al, 2017b) and, if unchecked, majority shareholders can promote their own self-interest to the detriment of minority shareholders. The third example of agency problem is divergence of interests between corporate 'insiders' such as managers, directors and shareholders and others regarded as corporate 'outsiders' (Roe, 2000; Enriques et al, 2017b). Being the ones in control of the corporation, corporate insiders can ignore the interests, and even act to the detriment, of the outsiders. 
The Anglo-American corporate governance model (Keay, 2010) traditionally regards nonshareholder groups like employees, creditors and consumers as outsiders who have no participation and representation rights. This 'shareholder primacy' model exclusively recognises the shareholder class in corporate governance and prioritises shareholders' interests over and above the interests of other corporate constituencies. The model also equates shareholders' interest with profit-making and, as a result, directs corporate managers and directors to pursue profit maximisation. Accordingly, Milton Friedman (1970) argued that 'there is one and only one social responsibility of business - to use its resources and engage in activities designed to increase its profits so long as it stays within the rules of the game, which is to say, engages in open and free competition without deception or fraud.' Similarly, in Dodge $v$ Ford Motor Co, the court stated that 'a business corporation is organised and carried on primarily for the profit of the shareholders... and the powers of the directors are to be employed for that end. ${ }^{32}$

Clearly, that the shareholder primacy model has little room for representing the interests of non-shareholders like proximate consumers and future generations in corporate governance. The alternative stakeholder model offers for protection of sustainable development in corporate governance. This is highlighted, for example, in Lyonnais Bank v. Pathe Communications ${ }^{33}$ where the court upheld a corporate 'obligation to the community of interests that sustained the corporation, to exercise judgment in an informed, good faith effort to maximize the corporation's long-term wealth creating capacity.' The stakeholder corporate governance

\footnotetext{
${ }^{32}$ Dodge v Ford Motor Co [1919] 170 NW 668, 684.

${ }^{33}$ Lyonnais Bank Nederland, N. Vv Pathe Communications Corp Civ. A. No. 12150, 1991 WL 277613 (Del. Ch. Dec. 30, 1991).
} 
model can provide opportunities for representing the interests of proximate consumers, future generations and stakewatcher groups in various ways, including voting and veto rights, membership of, and nomination to, the board of directors, incorporation of interests in directors' duties, accountability of directors, consultation rights and disclosure requirements.

\subsubsection{International cooperation}

As discussed above, the septet framework is completed by the consideration of the developing country context, including possible existence of institutional voids. We draw on the SDGS and the UN Guidelines for Consumer Protection to argue that international cooperation is imperative is necessary for implementing appropriate standards for sustainable consumption and production, especially when developing countries are involved. While Targets $6 \mathrm{a}$ and $16 \mathrm{a}$ of the SDGs and Part VI (articles 79-94) of the UN Guidelines for Consumer Protection stress the need for 'international cooperation' especially in the developing country context, lack of coordination between different national political institutions, especially those sharing geographical and socio-cultural affinities is problematic. The presumption against extraterritoriality of regulation and enforcement ${ }^{34}$ has aggravated the existence of institutional voids in some developing countries. The dirty fuel and toxic tobacco cases and their Africaspecific products highlight international or regional coordination as one of the obstacles to sustainable consumption in developing countries. This creates regulatory arbitrage that some businesses can exploit to provide harmful products or use unsustainable production systems. International cooperation can facilitate improved regulatory standards which, for example, resulted from the dirty fuel campaign (Yoboué, and Kaufman, 2018).

${ }^{34}$ Kiobel v Royal Dutch Petroleum Co, 133 S Ct 1659 (2913) 1669. 
International cooperation can help to improve the effectiveness of enforcement of standards. This is one of the justifications of the EU Consumer Protection Cooperation Regulation 2006/2004. ${ }^{35}$ It may therefore be helpful for groups of developing countries to enter into agreements covering matters like administrative and technical cooperation, information sharing, formulation and application of rules and standards and the enforcement of decisions.

\subsection{Conclusion}

The septet framework developed in this chapter provides the basis for fresh insights that challenge conventional approaches in consumer protection, contract law and regulatory standards and enforcement. It is argued that the concepts of consumer vulnerability, disclosure regulation, contract law, consumer responsibilisation, stakeholder, corporate governance, institutional voids and international cooperation can be reframed to advance the six essential dimensions of sustainable consumption in developing countries. The septet framework promotes shared responsibility for sustainable consumption and production between consumers and other institutional actors like governments, corporations and public interest organisations.

The notion of sustainable consumption and production, which has become increasingly popular as demonstrated by the SDGs and the UN Guidelines for Consumer Protection, shows that

35 Regulation (EC) No 2006/2004 of the European Parliament and of the Council of 27 October 2004 on cooperation between national authorities responsible for the enforcement of consumer protection laws (the Regulation on consumer protection cooperation) OJ L 364, 9.12.2004, pp.1-11. 
consumers can make a real difference to the sustainable development agenda as institutional champions. Consumption can encourage sustainable individual behaviour and business practices and protect the interests of future generations. Sustainable production is indeed one of the prosocial activities expected of businesses by stakeholders like consumers, including within the umbrella of CSR. In turn, the pursuit of sustainable development can make a significant difference for consumers, especially in developing countries. Proximate consumers and future generations are potential victims of unsustainable business practices. This is particularly the case in some developing countries which, due to institutional voids, provide inadequate substantive consumer protection standards and enforcement.

Unlike existing studies that focus mainly on consumer behaviour and lifestyle choices, this chapter draws on the legal, institutional and stakeholder perspectives to uniquely unbundle the concept of sustainable consumption and apply it to the developing country context. The chapter shows that the concept of sustainable consumption and production has six foundational components: (a) sustainable consumption by proximate consumers for future generations; (b) sustainable production for future generations; (c) sustainable consumption by/for proximate consumers; sustainable production for proximate consumers; (e) participation by proximate consumers; and corporate social responsibility. The developing country dimension caps the novel septet approach adopted by the chapter which stresses the need to fill institutional voids that can impede sustainable development. To illustrate the practical relevance of the septet framework, the chapter maps it out with the SDGs' provisions on sustainable consumption and production.

The chapter provides original proposals for an interventionist consumer protection model for sustainable consumption that includes public interest-oriented disclosure regulation, 
distributive justice-oriented contract law, resolution of business-to-consumer information asymmetry, credible corporate social reporting and certification standards, distributed/shared consumer responsibilisation model, stakeholder enforcement rights, obligations and protection, independent stakeholder determination of standards, resolution of related agency problem through a stakeholder approach to corporate governance and international cooperation in regulatory standards and enforcement. A consumer protection approach to sustainable development can promote stakeholder engagement and meaningful CSR by corporations.

The chapter therefore demonstrates the roles of consumers as institutional actors and consumption as an institution within the institutional theoretic model are context-specific. It is important to consider the institutional environment, especially where consumers are disadvantaged due to the legal and political institutions and the stronger position of economic institutions like corporations. Consequently, there is the need to align sustainable consumption and production to sustainable development in developing countries by designing and implementing an effective consumer protection model that may depart from the typical approaches of the more developed countries. The septet framework for sustainable consumption and production can facilitate private enforcement of international best standards and a consumer protection regime with horizontal impact even when vertical regulation and enforcement is weak.

\section{References:}

Acemoglu, D. (2009). Introduction to Modern Economic Growth, Princeton: Princeton University Press. 
Acemoglu, D., Johnson, S. and Robinson, J. (2005). Institutions as a Fundamental Cause of Long- Run Growth in P. Aghion and S. Durlauf, eds., Handbook of Economic Growth Volume 1A, Amsterdam: Elsevier, pp.386-472.

Acemoglu, D., Johnson, S. and Robinson, J.A. (2002), Reversal of Fortune: Geography and Institutions in the Making of the Modern World Income Distribution. Quarterly Journal of Economics, 107(4), pp.1231-1294.

Aghion, P., and Howitt, P. (2009). The economics of growth, Cambridge: MIT Press.

Akinbami, F. (2011). Financial services and consumer protection after the crisis. International Journal of Bank Marketing, 29(2), pp.134-147.

Aldohni, A. (2017). The UK new regulatory framework of High-Cost Short-Term Credit: Is there a shift towards a more "Law and Society" based approach? Journal of Consumer Policy, 40(3), pp.321-345.

Altschuller, S.A., Lehr, A. and Orsmond, A.J. (2010). Corporate social responsibility. The International Lawyer, 45(1), pp.179-189.

Anabtawi, I. and Stout, L. (2008). Fiduciary Duties for Activist Shareholders. Stanford Law Review, 60(5), pp.1255-1308.

Andorfer, V., and Liebe, U. (2013). Consumer behavior in moral markets. On the relevance of identity, justice beliefs, social norms, status, and trust in ethical consumption. European Sociological Review, 29(6), pp.1251- 1265.

Andorfer,V. and Liebe, U. (2015). Do information, price, or morals influence ethical consumption? A natural field experiment and customer survey on the purchase of fair trade coffee. Social Science Research, 52, pp.330-350. 
Antonetti, P. and Maklan, S. (2014). Feelings that make a difference: How guilt and pride convince consumers of the effectiveness of sustainable consumption choices. Journal of Business Ethics, 124(1), pp.117-134.

Armour, J., Hansmann, H. and Kraakman, R. (2017). Agency Problems and Legal Strategies. In R. Kraakman, J. Armour, P. Davies, L. Enriques, H. Hasnmann, G. Hertig, K. Hopt, H. Kanda, M. Pargendler, W. Ringe and E. Rock, eds., The Anatomy of Corporate Law: A Comparative and Functional Approach. Oxford: OUP, pp.29-48.

Baldwin, R., Cave, M. and Lodge, M. (2012). Understanding regulation: theory, strategy, and practice $2^{\text {nd }} E d$. New York: OUP.

Balmer, J. Powell, S. and Greyser, S. (2011). Explicating ethical corporate marketing. Insights from the BP deepwater horizon catastrophe: The ethical brand that exploded and then imploded. Journal of Business Ethics, 102, pp.1-14.

Bantekas, I. (2004). Corporate social responsibility in international law. Boston University International L.aw Journal, 22, pp.309-347.

Bar-Gill, O. and Warren, E. (2008). Making credit safer. University of Pennsylvania Law Review, 157(1), pp.1-101.

Barnett, C., Cloke, P., Clarke, N., and Malpass, A. (2011). Globalizing responsibilities: The political rationalities of ethical consumption. Oxford: Wiley-Blackwell.

Beck, T. and Levine, R. (2005), 'Legal Institutions and Financial Development' in C. Menard and M. Shirley (eds), Handbook of New Institutional Economics, Dordrecht: Springer.

Ben-Shahar, O. (2009). The Myth of the 'Opportunity to Read' in Contract Law. European Review of Contract Law, 5(1), pp.1-28. 
Berle, A. and Means, G. (1991). The Modern Corporation and Private Property, London: Transaction Publishers.

Bernd, H., Spraul, K. and Ingenhoff, D. (2016). Under positive pressure: How stakeholder pressure affects corporate social responsibility implementation. Business \& Society, 55(2), pp.151-187.

Black, B. (2001). The Legal and Institutional Preconditions for Strong Securities Markets. UCLA Law Review, 48(4), 781-856.

Black, I. (2010). Sustainability through anti-consumption. Journal of Consumer Behaviour, 9(6), pp.403-411.

Blake, J. (1999). Overcoming the 'value-action gap' in environmental policy: Tensions between national policy and local experience. Local Environment, 4, pp.257-278.

Bray, J. and Johns, N. (2011). An exploratory study into the factors impeding ethical consumption. Journal of Business Ethics, 98(4), pp.597-608.

Burnett, M. and Welford, R. (2007). Case study: Coca-Cola and water in India: Episode 2. Corporate Social Responsibility and Environment Management, 14(5), pp.298-304.

Campbell, C. L., Heinrich, D. and Schoenmüller, V. (2015). Consumers' reaction to fair trade motivated price increases. Journal of Retailing and Consumer Services, 24, pp.79-84.

Carrington, M.J., Zwick, D. and Neville, B. (2016). The ideology of the ethical consumption gap. Marketing Theory, 16(1), pp.21-38.

Cartwright, P. (2011). The vulnerable consumer of financial services: Law, policy and regulation. Available

at: https://www.nottingham.ac.uk/business/businesscentres/gcbfi/documents/researchreports/pap er78.pdf. (Accessed: 10 December 2018). 
Castaldo, S., Perrini, F., Misani, N. and Tencati, A. (2009). The missing link between corporate social responsibility and consumer trust: The case of fair trade products. Journal of Business Ethics, 84, pp.1-15.

Cedillo Torres, C.A., Garcia-French, M., Hordijk, R., Nguyen, K. and Olup, L. (2012). Four case studies on corporate social responsibility: Do conflicts affect a company's corporate social responsibility policy? Utrecht Law Review, 8(3), pp.51-73.

Centre for International Environmental Law (CIEL). (2017). Are Belgium and the Netherlands in breach of their international obligations under the Basel Convention and customary international law due to their export of high sulfur fuels to certain developing countries in Africa that are Parties of the Bamako Convention? Available at: http://www.ciel.org/wpcontent/uploads/2017/02/High-sulfur-fuels_CIEL-legal-opinion-23_01_2017-.pdf. (Accessed: 10 December 2018).

Chang, H.A.J. (2011). Institutions and Economic Development: Theory, Policy and History, Journal of Institutional Economics, 7(4), pp.473-498.

Cheffins, B. (2001), 'Does Law Matter? The Separation of Ownership and Control in the United Kingdom’ Journal of Legal Studies, 30(2), pp.459-484.

Cherednychenko, O. (2010). Conceptualizing unconscionability in the context of risky financial transactions: how do converge public and private law approaches? In M. Kenny, J. Devenney and L. Fox O’Mahony, eds., Unconscionability in European Private Financial Transactions. Cambridge: Cambridge University Press, pp.246-274.

Cherrier, H., Szuba, M. and Özçağlar-Toulouse, N. (2012). Barriers to downward carbon emission: Exploring sustainable consumption in the face of the glass floor. Journal of Marketing Management, 28(3/4), pp.397-419. 
Christian Aid (2018). Counting the cost: A year of climate breakdown. December 27, 2018. London: Christian Aid.

Clarke, N., Barnett, C., Cloke, P., and Malpass, A. (2007). Globalising the consumer: Doing politics in an ethical register. Political Geography, 26(3), pp.231-249.

Clarkson, J. J., Janiszewski, C. and Cinelli, M. D. (2013). The desire for consumption knowledge. Journal of Consumer Research, 39(6), pp.1313-1329.

Coase, R. (1960). The problem of social cost, Journal of Law and Economics, 3, pp.1-44.

Coase, R. (1975). Economists and public policy. In J.F Weston, ed., Large corporations in a changing society, New York: New York University Press.

Coffee, J.C. (2001). The Rise of Dispersed Ownership: The Roles of Law and the State in the Separation of Ownership and Control. Yale Law Journal, 111, pp.1-82.

Coffee, J.C. (2007). Law and the Market: The Impact of Enforcement. University of Pennsylvania Law Review, 156(2), pp.229-312.

Collins, H. (1992). Distributive justice through contracts. Current legal Problems, 45(2), pp.49-67.

Collins, H. (2004). Regulating contract law. In C. Parker, C. Scott, N. Lacey and J. Braithwaite, eds., Regulating law. Oxford: Oxford University Press, pp.13-32.

Crête, R. (2016). The Volkswagen scandal from the viewpoint of corporate governance. European Journal of Risk Regulation, 7(1), pp.25-31.

Dam, K. (2006), The Law-Growth Nexus, Washington D.C.: Brookings Institution.

Darnall, N., Ji, H. and Vázquez-Brust, D.A. (2018). Third-party certification, sponsorship, and consumers' ecolabel use. Journal of Business Ethics, 150(4), pp.153-169. 
de Jonge, A. (2011). Transnational corporations and international law: bringing TNCs out of the accountability vacuum. Critical Perspectives on International Business, 7(1), pp.66-89.

Department for Business, Innovation and Skills (DBIS). (2010). Corporate law and governance. The future of narrative reporting: a consultation. Available at: https://www.gov.uk/government/consultations/the-future-of-narrative-reporting-aconsultation. (Accessed: 10 December 2018).

Deva, S. (2012). Regulating corporate human rights violations, London: Routledge.

Doh, J.P., Littell, B. and Quigley, N.R. (2015). CSR and sustainability in emerging markets: Societal, institutional, and organizational influences. Organizational Dynamics, 44(2), pp.112120.

Domurath, I. (2013). The case for vulnerability as the normative standard in European consumer credit and mortgage law - An inquiry into the paradigms of consumer law. Journal of European Consumer and Market Law, 2(3), pp.124-137.

Doorey, D. (2011). The transparent supply chain: From resistance to implementation at Nike and Levi-Strauss. Journal of Business Ethics, 103, pp.587-603.

Easterbrook, F., and Fischel, D. (1984). Mandatory disclosure and the protection of investors, Virginia Law Review 70, pp.669-715.

Easterly, W. (2008). Institutions: Top Down or Bottom Up? American Economic Review: Papers and Proceedings, 98(2), pp.95-99.

Eckhardt, G. M., Belk, R. and Devinney, T. M. (2010). Why don't consumers consume ethically? Journal of Consumer Behaviour, 9(6), pp.426-436.

Enriques, L., Hansmann, H. and Kraakman, R. (2017a). The interests of shareholders as a class. In R. Kraakman, J. Armour, P. Davies, L. Enriques, H. Hasnmann, G. Hertig, K. Hopt, H. 
Kanda, M. Pargendler, W. Ringe and E. Rock (eds), The Anatomy of Corporate Law: A Comparative and Functional Approach, 3rd edn, Oxford: OUP, pp.55-88.

Enriques, L., Hansmann, H. and Kraakman, R. (2017b). The basic governance structure: Minority shareholders and non-shareholder constituencies. In R. Kraakman, J. Armour, P. Davies, L. Enriques, H. Hasnmann, G. Hertig, K. Hopt, H. Kanda, M. Pargendler, W. Ringe and E. Rock (eds), The Anatomy of Corporate Law: A Comparative and Functional Approach, 3rd edn, Oxford: OUP, pp.89-114.

European Commission (2015). Closing the loop - An EU action plan for the Circular Economy. $\operatorname{COM}(2015) \quad 614 \quad$ final. $\quad$ Available at: $\underline{\text { https://eur- }}$ $\underline{\text { lex.europa.eu/resource.html?uri=cellar:8a8ef5e8-99a0-11e5-b3b7- }}$ 01aa75ed71a1.0012.02/DOC_2\&format=PDF. (Accessed: 10 December 2018).

European Commission (2017). EU action to curb air pollution by cars: Questions and answers. http://europa.eu/rapid/press-release_MEMO-17-2821_en.htm.(Accessed: 10 December 2018). European Commission (2018). A European strategy for plastics in a circular economy. $\operatorname{COM}(2018) \quad 28$ final. Available at: lex.europa.eu/resource.html?uri=cellar:2df5d1d2-fac7-11e7-b8f501aa75ed71a1.0001.02/DOC_1\&format=PDF. (Accessed: 10 December 2018).

Evans, D. (2011). Thrifty, green or frugal: Reflections on sustainable consumption in a changing economic climate. Geoforum, 42(5), pp.550-557.

Evans, D. (2018). What is consumption, where has it been going, and does it still matter? The Sociological Review. Available at: https://doi.org/10.1177/0038026118764028. (Accessed: 10 December 2018). 
Evans, D., Welch, D. and Sawffield, J. (2017). Constructing and mobilizing 'the consumer': Responsibility, consumption and the politics of sustainability. Environment and Planning, A0(0), pp.1-17.

Fairweather, K., Grantham, R. and O'Shea, P. (2017). Credit, consumers and the law: After the global storm, Abingdon: Routledge.

Falkner, R. (2008). Business power and conflict in international environmental politics, Palgrave Macmillan.

Falletti, T.G., and Cunial, S.L. (2018). Participation in social policy: Public health in comparative perspective. New York: Cambridge University Press.

Fassin, Y. (2009). The stakeholder model refined. Journal of Business Ethics, 84(1), pp.113135.

Fejos, A. (2015). Achieving safety and affordability in the UK payday loans market. Journal of Consumer Policy, 38(2), pp.181-202.

Fejos, A. (2018). Social justice in EU financial consumer law. Tilburg Law Review, 24(1), pp.68-88.

Financial Services Authority (FSA). (2009). Mortgage market review. Available at: www.fsa.gov.uk/pubs/discussion/dp09_03.pdf (Accessed: 15 August 2018).

Francioni, F. (1991). Exporting environmental hazard through multinational enterprises: Can the state of origin be held responsible? In F. Francioni and T. Scovazzi, eds., International responsibility for environmental harm. London: Graham \& Trotman, pp.275-298.

Freeman, R.E. (1984). Strategic Management: A Stakeholder Approach, 1st edn. Boston: Pitman Publishing. 
Friedman, M. (1970), 'The Social Responsibility of Business is to Increase Its Profits' New York Times, 13 September.

Gabaldon, P. and Gröschl, S. (2015). A few good companies: Rethinking firms' responsibilities toward common pool resources. Journal of Business Ethics, 132, pp.579-588.

Gardner, J. (2017). High-Cost credit in the UK: A philosophical justification for government intervention. In K. Fairweather, R. Grantham, and P. O'Shea, eds., Credit, Consumers and the Law: After the Global Storm, Abingdon: Routledge, pp.132-152.

Gerding, E.F. (2009). The subprime crisis and the link between consumer financial protection and systemic risk. FIU Law Review, 5, pp.93-122.

Glaeser, E. and Shleifer, A. (2003). The rise of the regulatory state. Journal of Economic Literature, 41, pp.401-425.

Gray, R., Owen, D. and Adams, C. (1996). Accounting \& Accountability: Changes and Challenges in Corporate Social and Environmental Reporting, London: Prentice Hall.

Green, T. and Peloza, J. (2014). Finding the right shade of green: The effect of advertising appeal type on environmentally friendly consumption. Journal of Advertising, 43(2), pp.128141.

Greif, A. (2006), Institutions and the path to the modern economy: Lessons from medieval trade, Cambridge: CUP.

Guéniat, M., Harjono, M., Missbach, A. and Viredaz, G. (2016). Dirty diesel. How Swiss traders flood Africa with toxic fuels. A Public Eye Investigation, Lausanne: Public Eye.

Hardy, G., O’Malley, K. and Brindle, B. (2018). The domino effect: Exposing the knock-on effects of consumer problems. Citizens Advice. 
Heilbrunn, J. (2004), 'Anti-corruption Commissions: Panacea or Real Medicine to Fight Corruption?' World Bank Institute Working Paper Series 37234. Online. Available at: http://siteresources.worldbank.org/WBI/Resources/wbi37234Heilbrunn.pdf. (Accessed: 15 August 2018)

Herlin, H. and Solitander, N. (2017). "Corporate social responsibility as relief from responsibility: NPO legitimizations for corporate partnerships in contested terrains", Critical Perspectives on International Business, 13(1), pp.2-22.

Hevia, M. (2013). The distributive understanding of contract law: Kronman on contract law and distributive justice. In Reasonableness and Responsibility: A Theory of Contract Law. Law and Philosophy Library, 101. Dordrecht: Springer Netherlands, pp.19-32.

Hills, J. and Welford, R. (2005). Case study: Coca-Cola and water in India. Corporate Social Responsibility and Environmental Management, 12(3), pp.168-177.

Hinton, E, and Goodman, M. (2010). Sustainable consumption: Developments, considerations and new directions. In M. Redclift, and G. Woodgate, eds., International handbook of environmental sociology 2nd Edn Cheltenham: Edward Elgar. pp.245-261.

HM Revenue and Customs. (2018). Carbon emissions tax. Available at: https://www.gov.uk/government/publications/carbon-emmisions-tax/carbon-emmisions-tax. (Accessed: 10 December 2018).

HM Treasury, Reforming financial markets, Cm 7667 (2009).

HM Treasury, A new approach to financial regulation: building a stronger system, Cm 8012 (2011).

HM Treasury, A new approach to financial regulation: securing stability, protecting consumers, Cm 8268. (2012). 
Hodgson, G. (2006). What are institutions? Journal of Economic Issues, 40, pp.1-25.

Hofsted, G. (1994). Cultures and organizations. London: HarperCollins.

House of Commons Environmental Audit Committee. Sustainability of the fashion industry inquiry. Available at: https://www.parliament.uk/business/committees/committees-az/commons-select/environmental-audit-committee/inquiries/parliament-2017/sustainabilityof-the-fashion-industry-17-19/ (Accessed: 26 November 2018).

Howells, G. (2005). The potential and limits of consumer empowerment by information. Journal of Law and Society 32(3), pp.349-370.

Huffman, M. (2010). Bridging the divide? Theories for integrating competition law and consumer protection. European Competition Journal, 6(1), pp.7-45.

Husted, B. (2015). Corporate social responsibility practice from 1800-1914: Past initiatives and current debates. Business Ethics Quarterly, 25(1), pp.125-141.

Incardona, R. and Poncibò, C. (2007). The average consumer, the unfair commercial practices directive, and the cognitive revolution. Journal of Consumer Policy, 30, pp.21-38.

Inderst, R. (2009). Retail finance: Thoughts on reshaping regulation and consumer protection after the financial crisis. European Business Organization Law Review, 10(3), pp.455-464.

International Union for Conservation of Nature and Natural Resources (ICUN). (1980). World Conservation Strategy: Living Resource Conservation for Sustainable Development. Gland, Switzerland: International Union for Conservation of Nature and Natural Resources. United Nations Environmental Programme and World Wildlife Fund.

Jackson, H. and Roe, M. (2009). Public and Private Enforcement of Securities Laws: Resourcebased Evidence. Journal of Financial Economics, 93(2), pp.207-238. 
Jensen, M.C. and Meckling, W.H. (1976). Theory of the Firm: Managerial Behaviour, Agency Costs and Ownership Structure' Journal of Financial Economics, 3(4), pp.305-360.

Johnstone, M.-L. and Tan, L. P. (2015). Exploring the gap between consumers' green rhetoric and purchasing behaviour. Journal of Business Ethics, 132, pp.311-328.

Karam, C.M. and Jamali, D. (2013). Gendering CSR in the Arab Middle East: An institutional perspective. Business Ethics Quarterly, 23(1), pp.31-68.

Keay, A. (2010). Stakeholder theory in corporate law: has it got what it takes. Richmond Journal of Global Law and Business, 9(3), pp.249-300.

Kidd Jr, D.L. and Daughtrey Jr, W.H. (2000). Adapting contract law to accommodate electronic contracts: Overview and suggestions. Rutgers Computer and Technology Law Journal, 26, pp.215-280.

Korhonen, J., Honkasalo, A. and Seppälä, J. (2018). Circular economy: The concept and its limitations. Ecological Economics, 143, pp.37-46.

Kronman, A.T. (1980). Contract law and distributive justice. Yale Law Journal, 89, pp.472511.

Kysar, D.A. (2005). Preferences for processes: Process/product distinction and the regulation of consumer choice. Harvard Law Review, 118, pp.525-641.

La Porta, R., Lopez-de-Silanes, F. and Schleifer, A. (2006). What Works in Securities Laws? Journal of Finance, 61(1), pp.1-32.

La Porta, R., Lopez-de-Silanes, F. and Schleifer, A. (2008). The Economic Consequences of Legal Origins. Journal of Economic Literature, 46(2), pp.285-332. 
La Porta, R., Lopez-de-Silanes, F., Schleifer, A. and Vishny, R.W. (1997). Legal Determinants of External Finance. Journal of Finance, 52(3), pp.1131-1150.

La Porta, R., Lopez-de-Silanes, F., Schleifer, A. and Vishny, R.W. (1998). Law and Finance. Journal of Political Economy, 106(6), pp.1113-1155.

La Porta, R., Lopez-de-Silanes, F., Schleifer, A. and Vishny, R.W. (2000). Investor Protection and Corporate Governance. Journal of Financial Economics, 58(1-2), pp.3-27.

La Porta, R., Lopez-de-Silanes, F., Schleifer, A. and Vishny, R.W. (1999). The Quality of Government. Journal of Law, Economics and Organisation, 15(1), pp.222-279.

Laming, H. (2017). Should the UK pay financial rewards to whistleblowers? Banker, 167(1096), pp.12-12.

Landis, J. (1938). The administrative process. New Haven: Yale University Press.

Llewelyn D., (1999). The Economic Rationale for Financial Regulation. Financial Services Authority FSA Occasional Papers on Financial Regulation. Available at: http://www.fsa.gov.uk/pubs/occpapers/op01.pdf. (Accessed: 15 August 2018).

Longo, C., Shankar, A. and Nuttall, P. (2019). 'It's not easy living a sustianble lifestyle': How greater knowledge leads to dilemmas, tensions and paralysis. Journal of Business Ethics, 154(3), pp.759-779.

Lucy, W.N.R. (1989). Contract as a mechanism of distributive justice. Oxford Journal of Legal Studies, 9(1), pp.132-147.

Mansvelt, J. (2005). Geographies of consumption. London: SAGE. 
Maurisse, M. (2019). The blazing success of Swiss cigarettes in Africa: An investigation by Marie Maurisse, winner of Public Eye's investigation award. Available at: http://stories.publiceye.ch/tobacco/. (Accessed: 18 February 2019).

Micklitz, H. (2012). The expulsion of the concept of protection from the consumer law and the return of social elements in the civil law: A bittersweet polemic. Journal of Consumer Policy, 35, pp.283-296.

Micklitz, H. (2013). Do consumers and businesses need a new architecture of consumer law? A thought-provoking impulse. Yearbook of European Law, 32(1), pp.266-367.

Miles, J. (2009). Agreements for grown-ups. Cambridge Law Journal, 68(2), pp.285-288.

Miles, S. (2017). Stakeholder theory classification: a theoretical and empirical evaluation of definitions. Journal of Business Ethics, 142(3), pp.437-459.

Miller, D. (2013). Justice for earthlings. Cambridge: Cambridge University Press.

Modigliani, F. and Perotti, E. (1997). Protection of Minority Interest and the Development of Security Markets. Managerial and Decision Economics, 18(7), pp.519-528.

Monye, F. (2017). An overview of consumer law in Nigeria and relationship with laws of other countries and organisations. Journal of Consumer Policy, 41(4), pp.373-393.

Myles, P., Schick, L. and Okonta, O. (2018). Special Report: Nigeria's gas flare increase ahead 2020 deadline. Premium Times, Nigeria 25 November. Available at: https://www.premiumtimesng.com/news/headlines/297472-special-report-nigerias-gas-flaresincrease-ahead-2020-deadline.html (Accessed: 25 November 2018).

Newholm, T., Newholm, S. and Shaw, D. (2015). A history for consumption ethics. Business History, 57(2), pp.290-310. 
Nield, S. (2010). Responsible Lending and Borrowing: Whereto Low-Cost Home Ownership? Legal Studies, 30(4), pp.610-632.

North, D. (1990), Institutions, institutional change and economic performance. Cambridge: CUP.

OECD. (2009). Draft recommendation of the council on good practices on financial education and awareness to tating credit. Available at: https://one.oecd.org/document/C(2009)62/en/pdf. (Accessed: 15 August 2018).

OECD. (2011). OECD guidelines for multinational enterprises 2011 edition. Available at: http://www.oecd.org/corporate/mne/oecdguidelinesformultinationalenterprises.htm. (Accessed: 15 August 2018)

Omoteso, K. and Yusuf, H. (2017). Accountability of transnational corporations in the developing world: the case for an enforceable international mechanism. Critical Perspectives on International Business, 13(1), pp.54-71.

Osuji, O. (2011). Transnational corporations and the protection of human rights: Non-financial reporting as an option. In D. Nault and SL England (ed.), Globalization and human rights in the developing world. New York: Palgrave Macmillan, pp.83-117.

Osuji, O. (2012). Corporate social responsibility- fairness and promise as the fundaments for juridification of social disclosures. Contemporary Issues in Law, 12(1), pp.46-76.

Osuji, O. (2015). Corporate social responsibility, juridification and globalization: 'Inventive interventionism' for a 'paradox'. International Journal of Law in Context, 11(3), pp.1-34.

Osuji, O. (2017). Responsible lending: Consumer protection and prudential regulation perspectives. In K. Fairweather, P. O'Shea and R. Grantham (eds.), Credit, consumers and the law: After the global storm. Abingdon: Routledge, pp.62-85. 
Osuji, O. and Obibuaku, U. (2016). Rights and corporate social responsibility: competing or complementary approaches to poverty reduction and socioeconomic rights? Journal of Business Ethics, 136(2), pp.329-347.

Overton L. and Fox, L. (2018). Stakeholder Conceptions of Later-Life Consumer Vulnerability in the Financial Services Industry: Beyond Financial Capability? Journal of Consumer Policy, 41(3), pp.273-295.

Owens, S. (2000). Engaging the public: Information and deliberation in environmental policy. Environment and Planning, A32(7), pp.1141-1148.

Perera, C., Auger, P. and Klein, J. (2018). Green consumption practices among young environmentalists: A practice theory perspective. Journal of Business Ethics, 152, pp.843-864.

Polinsky, M. and Shavell, S. (2000). The economic theory of public enforcement of law. Journal of Economic Literature, 38, pp.45-76.

Reich, N. (1992). Diverse approaches to consumer protection philosophy. Journal of Consumer Policy, 14(3), pp.257-292.

Roe, M.J. (2000). Political conditions to separating ownership from control. Stanford Law Review 53(3), pp.539-606.

Rowan, S. (2009). Protecting contractual expectations: An Australian perspective. 68(2) Cambridge Law Journal, 68(2), pp.276-278.

Rutherford, M. (2001). Institutional Economics: Then and Now. Journal of Economic Perspectives, 15(3), pp.173-194.

Scherer, A. and Palazzo, G. (2011). The new political role of business in a globalized world: a review of a new perspective on CSR and its implications for the firm, governance, and democracy. Journal of Management Studies, 48(4), pp.899-931. 
Shamir, R. (2008). The Age of responsibilization: On market-embedded morality. Economy and Society, 37, pp.1-19.

Shaw, D., McMaster, R. and Newholm, T. (2016). Care and commitment in ethical consumption: An exploration of the 'attitude-behaviour gap'. Journal of Business Ethics, 136, pp.251-265.

Shove, E. (2004). Changing human behaviour and lifestyle: A challenge for sustainable consumption? London: Elgar Publishing.

Shove, E. (2010). Beyond the ABC: Climate change policy and theories of social change. Environment and Planning, A 42(6), pp.1273-1285.

Smith, A. (1776), An Inquiry into the Nature and Causes of the Wealth of Nations, London: W. Strahan and T. Cadell.

Spindler, G. (2011). Behavioural finance and investor protection regulations. Journal of Consumer Policy, 34, pp.315-336

Stadler, L. and Lin, H. (2019). Leveraging partnerships for environmental change: The interplay between the partnership mechanism and the targeted stakeholder group. Journal of Business Ethics, 154(3), pp.869-891.

Strengers, Y. and Maller, C., eds., (2015). Social practices, intervention and sustainability: Beyond behaviour change. London: Routledge.

Thøgersen, J., de Barcellos, M. D., Perin, M. G. and Zhou, Y. (2015). Consumer buying motives and attitudes towards organic food in two emerging markets: China and Brazil. International Marketing Review, 32(3/4), pp.389-413. 
Unilever (2017). Report shows a third of consumers prefer sustainable brands. 5 January 2017. Available at: https://www.unilever.com/news/press-releases/2017/report-shows-a-third-ofconsumers-prefer-sustainable-brands.html. (Accessed: 15 August 2018).

United Nations (2002). Report of the world summit on sustainable development. Johannesburg, South Africa, 26 August-4 September 2002. A/CONF.199/20. Available at: http://www.undocuments.net/aconf199-20.pdf (Accessed: 15 August 2018).

United Nations (2012). A 10-year framework of programmes on sustainable consumption and production $\quad$ patterns. $\quad$ A/CONF.216/5. Available at: http://www.un.org/ga/search/view_doc.asp?symbol=A/CONF.216/5\&Lang=E. (Accessed: 15 August 2018).

United Nations (2016). United Nations guidelines for consumer protection. New York: United Nations.

United Nations Environment Programme (UNEP). (2016). Diesel fuel sulphur levels: Global status $\quad 2016 . \quad$ June ailable at: http://www.unep.org/Transport/New/PCFV/pdf/Maps_Matrices/world/sulphur/MapWorldSul phur_June2016.pdf, (Accessed: 30 December 2016).

United Nations. (1987). Report of World Commission on Environment and Development: Our Common Future (Brundtland Report). Available at: http://www.un-documents.net/ourcommon-future.pdf, (Accessed: 1 December 2018).

United Nations. (2015). Transforming our world: The 2030 agenda for sustainable development. Available at: http://www.un.org/ga/search/view_doc.asp?symbol=A/RES/70/1\&Lang=.(Accessed: August 2018). 
Van Dam, C. (2011). Tort law and human rights: brothers in arms. Journal of European Tort Law, 2(3), 221-254.

Vogel, D. (2005). Social Responsibility. Washington, DC: Brookings Institution Press.

Whitmarsh, L., O’Neill, S. and Lorenzoni, I. (2010). Climate change or social change? Debate within, amongst, and beyond disciplines. Environment and Planning, A43, pp.258-261.

Willett, C. (2018). Re-theorising consumer law. Cambridge Law Journal, 77(1), pp.179-210.

Williams T. (2007). Empowerment of whom and for what? Financial literacy education and the new regulation of consumer financial services. Law \& Policy, 29(2), pp.226-256.

Winans, K., Kendall, A. and Deng, H. (2017). The history and current applications of the circular economy concept. Renewable and Sustainable Energy Reviews, 68(1), pp.825-833.

World Bank/Institute for Health Metrics and Evaluation University of Washington, Seattle (2013), The Cost of air pollution strengthening the economic case for action: World Bank, Washington.

World Health Organization (WHO). (2006). WHO Air quality guidelines for particulate matter, ozone, nitrogen dioxide and sulfur dioxide Global update 2005. Summary of risk assessment. Geneva: $\quad$ WHO Press. Available http://apps.who.int/iris/bitstream/10665/69477/1/WHO_SDE_PHE_OEH_06.02_eng.pdf, (Accessed: 30 November 2018).

Yoboué, M. and Kaufman, J. (2018). Inside the dirty fuels campaign: Lessons for business and human rights. Business and Human Rights Journal, 3(2), pp.291-297. 